\title{
Targeting B Cells and Plasma Cells in Autoimmune Diseases
}

\author{
Katharina Hofmann*, Ann-Katrin Clauder and Rudolf Armin Manz \\ Institute for Systemic Inflammation Research, University of Luebeck, Luebeck, Schleswig-Holstein, Germany
}

Success with B cell depletion using rituximab has proven the concept that B lineage cells represent a valid target for the treatment of autoimmune diseases, and has promoted the development of other B cell targeting agents. Present data confirm that B cell depletion is beneficial in various autoimmune disorders and also show that it can worsen the disease course in some patients. These findings suggest that B lineage cells not only produce pathogenic autoantibodies, but also significantly contribute to the regulation of inflammation. In this review, we will discuss the multiple pro- and anti-inflammatory roles of $\mathrm{B}$ lineage cells play in autoimmune diseases, in the context of recent findings using B lineage targeting therapies.

Keywords: B cells, IL-10+ B cell, autoantibodies, autoimmune disease, rheumatoid arthritis, rituximab, bortezomib

\section{INTRODUCTION}

The presence of autoantibodies is characteristic of most autoimmune diseases and has been widely used for diagnosis. Despite this, within the last 10-15 years B cells have been recognized as therapeutic targets for the treatment of autoimmune diseases. B cell subtypes, and the mechanisms of antibody production and maintenance, are highly diverse, and likewise the susceptibility of autoantibody-secreting plasma cells to therapies seems to be dependent on their tissue localization (1). Generally, conventional immunosuppressive therapy, using either steroids or cytostatic drugs, is commonly used in many autoimmune diseases and partly inhibits autoantibody production (2-5). At present, several drugs that specifically target B cells or plasma cells are either in clinical use or under development and promise to be very efficient for the treatment of various autoimmune diseases (6-8). Among them are (I) monoclonal antibodies against CD19, CD20, and CD22 that can directly target multiple B cell subtypes, but not or only to a lesser extent mature antibody-secreting plasma cells, (II) inhibitors of B cell activating factor (BAFF) and A proliferation-inducing ligand (APRIL), two cytokines which are very important survival factors for B cells and plasma cells, respectively, and (III) velcade/bortezomib, a small molecule proteasome inhibitor that spares B cells but eliminates both short-lived and long-lived plasma cells (9).

B cell directed therapies have proven not only to be therapeutically effective in classic B cell/ autoantibody-driven disorders, such as autoimmune blistering skin diseases, myasthenia gravis, or antibody/immune-complex-mediated systemic lupus erythematosus (SLE), but also in diseases that are believed to be mainly driven by T cells, most prominently rheumatoid arthritis (RA) or multiple sclerosis (MS) (10-12). By contrast, in some cases, therapeutic B cell depletion results in the aggravation of symptoms. These findings emphasize that $B$ cells play multiple roles that are relevant for the onset and clinical outcomes of autoimmune inflammatory disorders.

In this review, we will discuss how B cell targeting therapies may affect distinct B cell and plasma cell subpopulations, and how this depletion modulates the outcome of autoimmune diseases. 


\section{B CELLS, PLASMA CELLS, AND THEIR IMPACT ON AUTOIMMUNE DISEASES}

\section{B Cell Maturation and Subsets}

In humans and mice, there are three known functionally and phenotypically distinct $\mathrm{B}$ cell subsets: $\mathrm{B}-1, \mathrm{~B}-2$, and marginal zone (MZ) B cells (13). While B-1 and MZ B cells can contribute to innate and adaptive immunity, "conventional" B-2 cells provide adaptive humoral immunity.

B-1 cells arise already early in embryonic development and comprised about $5 \%$ of all B cells in mice and humans. The B-1 population is the major source of natural IgM antibodies that exhibit reactivity to self and common microbial antigens (14). B-2 cells are activated in T-dependent immune responses and produce antibodies of all subclasses, and are capable of forming memory B cells with increased antibody affinity. MZ B cells are found in the marginal sinus of the white pulp of the spleen and predominantly produce antibodies that are specific for carbohydrate antigens.

While autoantibodies contribute to the pathogenesis of many autoimmune disorders, natural autoantibodies can be protective (14-16), suggesting that the various B cell subsets play multifaceted roles in autoimmune diseases (17).

After birth, large numbers of immature B-2 B cells are continuously formed within the bone marrow (18). During the stepwise differentiation of B cell precursors into immature B cells, the genes encoding the $\mathrm{B}$ cell receptor are reorganized, which at the population level generates a heavily diverse antibody repertoire. Immature B cells express high levels of functional antigen receptors (antibodies) of the IgM subclass on their surface (19). Thereafter, based on the specificity and affinity of their individual B cell receptors, immature B cell clones are either negatively or positively selected (20).

Some immature B cells bearing an autoreactive B cell receptor become deleted by central tolerance mechanisms operative in the bone marrow. The immigration of immature B cells into the spleen occurs through the terminal branches of the central arteriole that drains into sinusoids of the MZ (21). After migration to the splenic follicles, non-self-reactive $\operatorname{IgM}^{+} / \operatorname{IgD}^{-}$immature $\mathrm{B}$ cells penetrate the $\mathrm{MZ}$ sinus to migrate through the interface between the periarteriolar lymphoid sheaths and B cell follicles, and eventually become $\operatorname{IgM}^{+} / \mathrm{IgD}^{+}$naive mature $\mathrm{B}-2$ or $\mathrm{MZ}$ $\mathrm{B}$ cells. This process is strongly dependent on high concentrations of the cytokine BAFF, which is expressed in splenic follicles. Most self-reactive immature B cells that passed central tolerance induction are energized or deleted in the spleen before they reach the BAFF-rich follicles. This peripheral tolerance mediating process relies on the activation of self-reactive $B$ cells by autoantigens, which results in arrest of migration before these cells can enter the splenic follicle, and as a consequence they die as a result of BAFFdeprivation (21). Despite this, autoantibodies are also found in healthy individuals $(22,23)$, suggesting that some autoreactive $B$ cells escape both the central and peripheral tolerance inducing mechanisms.

Mature B cells recirculate through the blood and accumulate in the follicles of secondary lymphoid tissues (24). Interestingly enough, mature B cells express a certain degree of migrational diversity. While all mature B cells are found in systemic and mucosal secondary lymphoid tissues, only a subpopulation of mature B cells recirculate through the bone marrow, a process of unknown biological significance, but which is clearly well controlled. In mice, these B cells express CD22, an Ig superfamily member serving as an adhesion receptor for sialic acid-bearing ligands. CD22 binds to CD22-ligands specifically present on sinusoidal endothelial cells in the bone marrow, but not on endothelial cells in other lymphoid tissues (25). A heterogeneous population of $\mathrm{B}$ cells also recirculates through the skin, as has been shown in animal models (26). These B cells express typical skin-homing receptors, e.g., ligands for E-selectin and $\alpha-4$ and $\beta-1$ integrins, and exhibit a different immunophenotype than lymph node B cells. It is thought that these cells activate T cells at the site of inflammation and can increase local antibody production (26). However, the possibility that skin-homing B cells contribute to autoimmune skin diseases remains to be established.

After stimulation with their cognate (self-) antigen, mature B cells eventually may form short-lived plasma cells, memory B cells, or long-lived plasma cells $(27,28)$. As discussed below, these cell types markedly contribute to the pathogenesis of autoimmune diseases and exhibit a specific response to distinct therapeutic approaches.

\section{Memory B Cells}

Memory B cells are formed within germinal centers and differ from naive B cells with respect to several features. While many human and murine memory B cells still express IgM, a significant proportion has already switched to the production of downstream antibody subclasses, mainly IgA and IgGs (29-31). Antigenmediated crosslinking of membrane IgG provides a much stronger activation signal than $\operatorname{IgM}(32)$, which contributes to the reduced activation threshold observed for memory $\mathrm{B}$ cells and their capacity to quickly give rise to antibody-secreting plasma cells (33-36). Independent from their subclass, memory B cells have down-regulated the expression of genes that negatively control BCR signaling and have up-regulated the expression of their counterparts $(37,38)$. Moreover, memory B cells also express higher affinity B cell receptors, which not only strengthens the effector functions of the antibodies secreted by their plasma cell progeny, but also allows memory $\mathrm{B}$ cells to sense very low antigen doses. Consequently, memory $\mathrm{B}$ cells resemble very powerful antigen-presenting cells (APCs) $(39,40)$. While dendritic cells definitively represent the most important APC during the initiation of the immune response, memory $\mathrm{B}$ cells may take over later. Hence, antigen-presentation by memory B cells might be of particular importance during the later phases of chronic immune reactions, such as autoimmune diseases. Human, but not murine, memory B cells show increased expression of CD27. The interaction of CD27 with its ligand on T cells, CD70, promotes the differentiation of activated memory $\mathrm{B}$ cells into plasma cells (41). Compared with naive cells, human memory B cells also exhibit a distinct expression profile of homing molecules; these molecules help B cells to interact with T cells and present their cognate antigen in the context of MHC class II in an optimal manner (42-47). The capacity to efficiently interact with $\mathrm{T}$ cells is crucial to quickly boosting both the formation of plasma cells 
and antibody secretion, but likely also increases the capacity of memory B cells to modulate $\mathrm{T}$ cell responses.

In conclusion, memory B cells are optimized to interact with T cells and to yield strong antibody responses even in response to relatively little stimulation. Autoreactive memory antibodies are likely to contribute to the chronic and progressive course typically observed for autoimmune disorders (48). High frequencies of memory B cells are associated with poor clinical responses to RTX treatment (49). RTX treatment results in the efficient depletion of memory B cells in peripheral blood, and relapse after this treatment is thought to be associated with the repopulation of IgD-CD27- and IgD-CD $27^{+}$memory B cells (50). However, RTX may not deplete the whole B cell memory compartment. RTXtreated patients can generate robust recall responses to repeated influenza vaccination, as indicated by the increase in serum antibody levels and peripheral blood plasmablast frequencies (51). This memory response is comparable to that observed in healthy controls. Hence, a significant fraction of memory B cells seems to be resistant to RTX treatment and is most likely localized in lymphoid or inflamed tissues (51). In mice, distinct layers of memory B cells have been identified, suggesting that the memory compartment is much more complex and diverse than expected $(52,53)$. Similarly, in human donors, distinct subpopulations of memory B cells that distinctly express homing receptors, such as CXCR3, have been observed in blood $(46,54)$. In response to IFN- $\gamma$, activated B cells upregulate CXCR3, which thereafter is stably expressed on their memory B cell progeny $(46,54)$. These findings may indicate that a subpopulation of memory B cells is formed under inflammatory conditions, such as during an autoimmune disease flare-up, which then might be able to migrate into inflammatory tissues where they are relatively protected from therapeutic intervention.

\section{Short-Lived and Long-Lived Plasma Cells}

Successful activation of naive B cells leads to a massive clonal expansion and eventually the formation of short-lived plasma cells in the extra-follicular areas of secondary lymphoid tissues (55). In mice, these cells exhibit lifetimes of less than a week (56). Cytostatic drugs, such as cyclophosphamide, prevent B proliferation and the formation of new antibody-secreting cells, hence eliminating the short-lived plasma cell compartment (57). Simultaneous to the formation of short-lived plasma cells, germinal centers may give rise to both memory $\mathrm{B}$ cells and long-lived plasma cells. For a brief period following vaccination, precursors of long-lived plasma cells (plasmablasts) are found in human peripheral blood (54); these cells then give home to deposit tissues, such as bone marrow, mucosal tissue, or sites of inflammation. The tissue homing of these cells is tightly regulated by adhesion molecules, chemokines, and their receptors (58-60). In peripheral blood, plasma cell subpopulations are found that exhibit different expression profiles of homing receptors. For example, migratory plasmablasts, induced by intracutaneous vaccination, express L-selectin, which are associated with homing to peripheral lymph nodes $(61,62)$. Similar to the return of locally activated plasma cell precursors to mucosal sites, cells that are activated in the context of a pro-inflammatory response seem to be programmed to relocate to inflamed tissues. Here, the high levels of inflammatory cytokines can support plasma cell survival, likely enabling these cells survive for the period of inflammation (60). These data suggest that plasma cells formed in the course of an inflammation-associated immune response can maintain the production of antibodies but will disappear when the cause of inflammation has resolved $(46,63)$.

In human tissues, various plasma cell subpopulations exist which exhibit different phenotypes and stages of differentiation $(46,64,65)$. Some plasma cell stages still express CD20, indicating that they might be susceptible to RTX treatment. However, mature human plasma cells have lost CD20 expression (66-68). Accordingly, even B cell depletion has been found to have no impact on the production of human memory antibodies, e.g., specific for tetanus toxoid (63). In general, serum antibodies of different specificities show a great variety of responses following $B$ cell depletion, ranging from no response to depletion below the detection limit (69), possibly suggesting that antibodies are maintained by various mechanisms, including short-lived plasma cell populations that are replenished by various memory B cell subsets and by long-lived plasma cells. The notion that long-lived plasma cells contribute to the production of autoantibodies (57), but are not affected by conventional immunosuppressive drugs such as steroids or cyclophosphamide, or by B cell depletion, has identified them as a novel target cell requiring specific therapeutic approaches (70).

\section{B Lineage Cells Exert Multiple Roles That Drive Pathogenesis but Also Control the Severity of Inflammation}

$\mathrm{B}$ cells play multiple functions. Following differentiation into plasma cells, they secrete huge amounts of antibodies into the body fluids. Autoantibodies can contribute to the pathogenesis of autoimmune diseases in multiple ways (71). They can initiate immune-complex-mediated inflammation, deplete specific cell types or modulate important signaling pathways, relevant in SLE, antibody-mediated hemolytic anemia or Hashimoto's thyroiditis and Graves' disease, respectively (72-75). However, more recent studies indicate that antibodies can also exert significant anti-inflammatory effects, which limit or even inhibit autoimmune pathogenesis. The pro- and anti-inflammatory effects of antibodies depend on their isotype (76) and on their Fc $N$-linked glycosylation patterns $(77,78)$. While IgGs with low levels of galactosylation promote inflammation, sialylated IgGs have a strong anti-inflammatory capacity $(79,80)$. Highly glycosylated IgG antibodies have been shown to inhibit autoimmune inflammation in mouse models $(76,81,82)$. Changes in autoantibody glycosylation have been observed during the course of human autoimmune diseases, possibly providing an interesting novel diagnostic tool, but also suggesting that the antibody glycosylation pattern can alter the clinical course of autoimmune disorders (83).

$\mathrm{B}$ lineage cells can also present antigens in the context of $\mathrm{MHC}$ II and secrete immunomodulatory cytokines, thereby playing a prominent role for the modulation of antigen-specific $\mathrm{T}$ cell responses (84-86). B cells probably only play a minor role in T cell priming. However, during secondary or chronic immune reactions B cells resemble very potent APCs that drive the expansion 
of activated T helper cells (87-90). Hence, B cells are likely to be both important antigen-presenting and $\mathrm{T}$ cell promoting cells during chronic and repeated immune reactions, such as occurs during the course of autoimmune diseases.

In addition, various $B$ lineage cells, including those with a $\mathrm{CD}_{138^{+}}$plasmablast/plasma cell phenotype, have been shown to express a variety of pro-inflammatory cytokines that can stimulate innate effector cells and significantly contribute to inflammation and immune protection in murine models (91-93). Moreover, while some B lineage cells promote inflammation, others exhibit profound immunosuppressive capacities (94). As shown in many models, B cells and plasma cells can also suppress autoimmune inflammation through the production of cytokines, such as IL-10, TGF-beta, or IL-35 (86, 95-98). Interestingly, IL-10 and IL-35 are produced by B cells that have different phenotypes (98). As discussed below, the therapeutic induction of immunosuppressive $B$ lineage cells may be an interesting direction for the development of future therapies.

\section{LESSONS FROM RTX TREATMENT OF AUTOIMMUNE DISEASES}

Regarding the clinical use of B cell targeting therapies, the majority of the information comes from studies using RTX. This chimeric mouse/human monoclonal antibody targets the pan B cell marker CD20, a transmembrane protein expressed on all B lineage cells, from early pre-B to mature B and memory $B$ cells. CD20 has been shown to mediate $\mathrm{Ca}^{2+}$ influx across plasma membranes and is important in maintaining intracellular $\mathrm{Ca}^{2+}$ concentration and activation of B cells (99). RTX was the first anti-CD20 antibody approved by the U.S. Food and Drug Administration for medical use in 1997 as Rituxan ${ }^{\circledR}$, originally to treat B cell non-Hodgkin lymphomas (100). Later it was also approved for use in RA, granulomatosis with polyangiitis, and microscopic polyangiitis and there is growing clinical use of RTX in other autoimmune diseases, such as MS, SLE, and autoimmune blistering skin diseases (101-105).

\section{Mode of Action of RTX}

After binding of RTX to membrane bound CD20 it mediates strong complement-dependent cytotoxicity directed to its target cell due to the enhanced clustering of antibody Fc regions (106, 107). Based on its ability to redistribute CD20 into lipid rafts, which provides the molecular basis for RTXs engagement of complement factors, RTX is classified as a type I anti-CD20 antibody. By contrast, type II antibodies cannot cause this redistribution of CD20 (108-111), do not induce complement-dependent cytotoxicity to the same extent (111), but appear to induce a greater degree of directly induced, non-apoptotic cell death, upon binding to target cells (112).

CD20 expression is lost during differentiation into mature antibody-secreting plasma cells (66-68). This lack of CD20, particularly on long-lived plasma cells, explains why RTX treatment does not interfere with the production of memory antibodies, such as anti-tetanus/-measles/-mumps/-rubella (63, 113). Depending on the stage of plasma cell differentiation and tissue localization, early plasma cells (plasmablasts) exhibit various levels of CD20 expression (114). While mature long-lived plasma cells are apparently not depleted by RTX, it is not known to which extent earlier plasma cell stages are affected.

Independent of disease, RTX leads to the depletion of peripheral B cells from approximately $90 \%$ to close to $100 \%$ (Table 1). Despite this fact, the clinical efficacy of RTX varies broadly among different autoimmune diseases, and also among individual patients. Following withdrawal of RTX treatment, B cell levels recover within 6-20 months, with the rate of recovery greatly varying between individual patients (115).

\section{Use of RTX in Pemphigus Vulgaris (PV)}

RTX has shown promising results in the treatment of PV, an autoantibody-driven blistering skin disease. In three independent clinical studies, comprising a total of 43 patients with this rare autoimmune disorder, RTX treatment achieved a complete remission in over $80-95 \%$ of patients $(103,116,117)$ who, importantly, were refractory to steroid therapy. This impressive clinical outcome was achieved in parallel with B cell depletion close to undetectable levels in almost all patients. One study showed that in most, but not all patients, the levels of anti-keratinocyte cell-surface IgG4 autoantibodies dropped to undetectable levels (116). In another study, anti-desmoglein 1 and 3 (Dsg1/3) autoantibodies were measured and found to be reduced on average by $65-80 \%$ (103). Generally, the response to RTX treatment seems to correlate with the extent of B cell depletion. However, two treated patients showed clinical remission despite persistent high levels of anti-Dsg1/3 autoantibodies, although remission was delayed compared with that in patients who showed remarkably reduced autoantibody levels (103). Hence, a reduction in the levels of autoantibodies seems to be a major factor in the success of RTX in treating PV. Nevertheless, the finding that RTX can improve clinical symptoms in patients that still exhibit high levels of anti-Dsg1/3 autoantibodies, suggests that RTX can also act via additional mechanisms. It would be interesting to consider this concept while designing future clinical studies.

\section{Use of RTX in RA}

Studies using RTX in RA have provided additional evidence that its therapeutic efficacy is not merely based on the reduction of autoantibody levels. In this disease, RTX is recommended for use in patients refractory to standard therapy (118). Although the $\mathrm{B}$ cell depletion rate is almost $100 \%$, a clinical response was observed in approximately $60-70 \%$ of patients $(11,105,119)$. Considering that these patients did not respond to other therapies, this was deemed to be a significant success. Results from more recent studies have suggested that RTX has better long-term efficacy when used in patients with fewer previous treatments and lower disease activity (120). Interestingly, the clinical response to RTX in RA positively correlates with the presence of anti-CCP autoantibodies, but is inversely correlated with the IgG-levels present before treatment (121-124). Autoantibodies and IgG-levels together with serum IL-33 have also been reported to predict the clinical response to RTX (125).

Based on the correlation between serum autoantibodies and response to RTX, on first view it seems possible that suppression 
TABLE 1 | Efficacy of RTX treatment varies.

\begin{tabular}{|c|c|c|c|c|c|c|c|c|c|}
\hline \multirow[b]{2}{*}{ Reference } & & \multirow{2}{*}{$\begin{array}{l}\text { RA } \\
\text { Emery et al. (11); } \\
\text { Rubbert-Roth et al. (105); } \\
\text { Haraoui et al. (119) }\end{array}$} & \multirow[b]{2}{*}{ Rovin et al. (145) } & \multicolumn{2}{|l|}{ SLE } & \multirow{2}{*}{$\begin{array}{l}\text { PV } \\
\text { Ahmed et al. (116); Joly et al. } \\
\text { (103); Pfütze et al. (117) }\end{array}$} & \multicolumn{3}{|c|}{ MS } \\
\hline & & & & $\begin{array}{l}\text { Leandro et al. (146); } \\
\text { Albert et al. (147) }\end{array}$ & Lu et al. (148) & & $\begin{array}{l}\text { Dunn et al. (150); } \\
\text { Cross et al. (104) }\end{array}$ & $\begin{array}{l}\text { Hauser } \\
\text { et al. (149) }\end{array}$ & $\begin{array}{l}\text { Hawker } \\
\text { et al. (151) }\end{array}$ \\
\hline Patient no. & & $120 / 346 / 465$ & 144 & 24 & 50 & $11 / 21 / 11$ & $16 / 399$ & 104 & 439 \\
\hline $\begin{array}{l}\text { Dose and } \\
\text { duration }\end{array}$ & & $1 \mathrm{mg}$ for $24 / 48$ weeks & $1 \mathrm{mg}$ for 52 weeks & $1 \mathrm{mg}$ for 6 months & $1 \mathrm{mg}$ for 6 months & $375 \mathrm{mg} / \mathrm{m}^{2}$ for 6 months & $\begin{array}{l}375 \mathrm{mg} / \mathrm{m}^{2} / 0.5-1 \mathrm{mg} \\
\text { for } 6 \text { months }\end{array}$ & $\begin{array}{l}1 \mathrm{mg} \text { for } \\
48 \text { weeks }\end{array}$ & $\begin{array}{l}1 \mathrm{mg} \text { for } \\
96 \text { weeks }\end{array}$ \\
\hline $\begin{array}{l}\text { Clinical } \\
\text { improvement }\end{array}$ & $\begin{array}{l}\text { Partial } \\
\text { Complete } \\
\text { No }\end{array}$ & $\begin{array}{l}\text { ACR20/50/70: } \\
\text { in 54-72/27-48/7-23\% } \\
- \\
\text { in } 5 \%\end{array}$ & $\begin{array}{l}\text { Proteinurea: } \\
\text { in } 26.4 \% \\
\text { in } 30.6 \% \\
\text { in } 43.1 \%\end{array}$ & $\begin{array}{l}\text { Proteinurea/BILAG/ } \\
\text { SLEDAl: } \\
\text { in } 65-70 \% \\
\text { - } \\
-\end{array}$ & $\begin{array}{l}\text { BILAG: } \\
\text { in } 42 \% \\
- \\
-\end{array}$ & $\begin{array}{l}\text { Skin lesions: } \\
\text { in } 8.2-20 \% \\
\text { in } 80-95 \% \\
-\end{array}$ & $\begin{array}{l}\text { EDSS: } \\
\text { in } 12.5-63.2 \% \\
- \\
\text { in } 36.8-81.25 \% \text { : } \\
\text { worse in } 6.25 \%\end{array}$ & $\begin{array}{l}\text { GELN: } \\
\text { in } 80.3 \% \\
\text { in } 19.7 \% \\
\text { - }\end{array}$ & $\begin{array}{l}C D P: \\
- \\
- \\
\text { in } 100 \%\end{array}$ \\
\hline $\begin{array}{l}\text { B cell depletion } \\
\text { efficacy in } \\
\text { periphery }\end{array}$ & & $\begin{array}{l}\text { Significant depletion } \\
\text { to } 6 \text { cells/ } \mu \mathrm{L}\end{array}$ & $\begin{array}{l}\text { Complete } \\
\text { depletion in 99\% }\end{array}$ & $\begin{array}{l}\text { Almost complete depletion } \\
\text { in } 94-96 \% \text { of patients }\end{array}$ & $\begin{array}{l}\text { Complete depletion in } 42 \% \text {; } \\
\text { partial depletion in } 47 \% \text { and } \\
\text { no depletion in } 11 \% \text { of patients }\end{array}$ & $\begin{array}{l}\text { In almost all patients } \\
\text { complete B cell depletion }\end{array}$ & $\begin{array}{l}\text { Depletion by } 95-99.8 \% \\
\text { in all patients; } 90 \% \\
\text { depletion in spinal fluid }\end{array}$ & $\begin{array}{l}\text { Over } 95 \% \\
\text { depletion in } \\
\text { all patients }\end{array}$ & \\
\hline $\begin{array}{l}\text { Autoantibody } \\
\text { involvement }\end{array}$ & & $\begin{array}{l}\text { Anti-CCP aab and } \\
\text { RF reduced by } 45 \%\end{array}$ & $\begin{array}{l}\text { Anti-dsDNA aab } \\
\text { reduced by } 75 \%\end{array}$ & $\begin{array}{l}\text { Anti-dsDNA aab reduced } \\
\text { by } 35 \%\end{array}$ & $\begin{array}{l}\text { Anti-dsDNA aab } \\
\text { reduced by } 60 \%\end{array}$ & $\begin{array}{l}\text { In } 81.8 \% \text { lgG/lgG4 anti- } \\
\text { keratinocyte cell-surface aab } \\
\text { undetectable; dramatic decrease } \\
\text { of IgG/lgG4 anti-Dsg1 (by 80\%) } \\
\text { and Dsg3 (by 65\%) aab }\end{array}$ & $\begin{array}{l}\text { Elevated serum anti- } \\
\text { MOG aab }\end{array}$ & - & \\
\hline Remark & & HACA in $2.3-7.3 \%$ & - & $\begin{array}{l}\text { HACA in } 33 \% \text {, correlating } \\
\text { with B cell depletion rate }\end{array}$ & & $\begin{array}{l}\text { Clear correlation between aab } \\
\text { and disease }\end{array}$ & $\begin{array}{l}\text { HACA in } 24.1-37 \% \text {, } \\
\text { correlates with B cell } \\
\text { depletion rate }\end{array}$ & $\begin{array}{l}\text { HACA in } \\
24.1 \% \text { of } \\
\text { patients }\end{array}$ & \\
\hline
\end{tabular}

RA, rheumatoid arthritis; SLE, systemic lupus erythematosus; PV, Pemphigus vulgaris; MS, multiple sclerosis; ACR, American College of Rheumatology Criteria, standard criteria to measure the effectiveness of arthritis treatments in clinical trials for rheumatoid arthritis, 20/50/70 refers to the improvement in tender or swollen joint counts as a percentage; HACA, human anti-chimeric antibodies; CCP, cyclic citrullinated peptides; RF, rheumatoid factor; MTX, methotrexate; MMF, methyl mofetil; Std, standard therapy; BILAG, British Isles Lupus Activity Group, organ-specific 86-question assessment based on the principle of the clinical intent to treat; SLEDAI, SLE Disease Activity Index, a list of 24 items (16 clinical items including seizure, psychosis, organic brain syndrome, visual disturbance, other neurological problems, hair loss, new rash, muscle weakness, arthritis, blood vessel inflammation, mouth sores, chest pain that worsens with deep breathing, and manifestations of pleurisy and/or pericarditis and fever, and eight laboratory results, including urinalysis testing, blood complement levels, increased anti-DNA antibody levels, low platelet count, and low white blood cell count); EDSS, Expanded Disability Status Scale is a method of quantifying disability in multiple sclerosis and monitoring changes in the level of disability; CDP, delayed time to confirmed disease progression; Dsg, desmoglein; CANCA, anti-neutrophil cytoplasmic antibodies; MOG, myelin oligodendrocyte glycoprotein; aab, autoantibodies; dsDNA, double-stranded DNA. 
of autoantibodies is a relevant mechanism by which RTX affects the clinical outcome of RA. The presence of autoantibodies such as rheumatoid factor (RF) and anti-CCP correlate well with disease activity in RA patients and indicate the presence and activation of autoreactive B cells. Moreover, anti-CCP and IgM-RF can enhance pro-inflammatory macrophage functions in vitro (126), supporting the idea that these autoantibodies may also contribute to RA pathogenesis in vivo. However, the reduction of serum autoantibody levels in RTX-treated responders is only very moderate, i.e., approximately 50 and $30 \%$, for antiCCP and RF, respectively, with a high degree of variation being observed (69). It seems questionable that such minor reductions in autoantibody levels cause the clinical response. Moreover, the absolute autoantibody levels persisting in responders after treatment were still two to fivefold higher than in non-responders (69). If autoantibodies in responders and non-responders exhibit similar pathogenicity, the moderate depletion of autoantibodies in responders to levels above of non-responders would not explain the success of the therapy. Other studies have also shown very moderate RTX effects on IgA and IgG anti-CCP autoantibodies, suggesting that a significant proportion is produced by long-lived plasma cells (127). The question of whether these antibodies contribute to RA pathogenicity remains to be addressed.

\section{RTX Effects on CD4 T Cells}

Alternative explanations for the anti-inflammatory effects of RTX in RA patients include the suppression of inflammatory $\mathrm{T}$ cells in favor of regulatory $\mathrm{T}$ cells subsets, possibly in combination with an induction of high galactosylated anti-inflammatory antibodies. There is good evidence that CD4 T cells can activate myeloid and synovial cells, which in turn activate and recruit macrophages to synovial tissue, eventually leading to joint inflammation and cartilage destruction, whereas regulatory $\mathrm{T}$ cells are protective (128-131).

The production of pro- and anti-inflammatory cytokines such IFN- $\gamma$, IL-17, or IL-10 seems to be key for T cell mediated control of RA pathogenesis. There is evidence that the clinical response to RTX therapy in RA is associated with lower IFN- $\gamma$ levels (132). Moreover, a study including 52 patients showed that RTX often induces a reduction in the number of peripheral blood CD4 T cells, an effect that was strongly associated with the clinical response (133). It is possible that the depletion of a small subpopulation of CD20 $0^{+} \mathrm{T}$ cells contributes to this effect (134).

However, there is good evidence that B cells can efficiently promote CD4 $\mathrm{T}$ cell functions through antigen-presentation and cytokine release. As discussed above, while B cells may play only a minor role in $\mathrm{T}$ cell priming, during secondary or chronic immune reactions, $\mathrm{B}$ cells can act as very potent APCs that drive the expansion of activated T helper cells $(87-89,135)$. Hence, $B$ cell depletion may impair the formation, clonal expansion, and function of T memory cells.

Accordingly, $\mathrm{T}$ cell activation in the synovium of RA patients has been reported to be dependent on B cells (136). Hence, it is highly likely that RTX mediates its beneficial effects in RA at least partly through the depletion of T cell stimulating B lineage cells, although this remains to be studied further.

\section{Effects of RTX Mediated B Cell Depletion on Cytokines}

Of note, under certain conditions, B cells can also directly promote innate inflammatory effector cells through the production of cytokines such as IFN- $\gamma$, IL-6, granulocyte-macrophage colony-stimulating factor, and IL-17 (91, 93, 137, 138). In mice, $\mathrm{B}$ cell ablation has been shown to ameliorate autoimmune diseases by depleting IL-6-producing B cells (93). Moreover, a recent study has provided evidence that B cells from RA patients show abnormal IL-6 signaling and altered cytokine production, and that this may contribute to disease (139). Hence, B cells resemble an underestimated source of inflammatory cytokines and the depletion of such pro-inflammatory cytokine producing B cells is likely to contribute to the therapeutic outcome of RTX treatment.

\section{RTX Effects on Antibody Glycosylation}

$\mathrm{T}$ cell help in germinal centers has been found to be important for the induction of inflammatory low-glycosylated IgG antibodies (82). In particular, the T cell-derived cytokines such as IFN- $\gamma$ and IL-17 are capable of synergistically promoting the production of low-sialylated, and potentially pathogenic, antibodies $(82,139)$. Based on the notion that the clinical response to RTX in RA is associated with lower IFN- $\gamma$ levels (132), it is possible that a reduction in IFN- $\gamma$ levels, in turn, leads to alterations in antibody glycosylation.

In accordance with the idea that these processes are of pathophysiological relevance, reduced antibody glycosylation has been reported to precede disease onset and to correlate with disease activity in RA patients (140). This phenotype is highly prevalent in, but not restricted to, autoantibodies (141). Hence, it is possible that acting through a reduction in IFN- $\gamma$ levels, RTX corrects the shift toward the production of pro-inflammatory antibodies that is observed in RA. Of note, high-glycosylated antibodies can mediate anti-inflammatory effects independent of their specificity, as indicated by the therapeutic effects of intravenously administered immunoglobulins (142), although antigen-specific effects might be considerably stronger and require lower antibody concentrations $(79,81,143)$. Accordingly, highly glycosylated IgGs have been reported to induce antigen-specific tolerance (78). Hence, RTX may partly mediate its beneficial effects through changes in antibody glycosylation, either via a reduction in autoantibody pathogenicity, through the generation of antiinflammatory autoantibodies, or by the induction of persistent high levels of anti-inflammatory total IgGs that mimic continuous IVIG treatment.

\section{Effects of RTX in MS and SLE}

Similar to what has been observed in RA, the therapeutic effect of RTX in SLE and MS is variable. Its impact on total antibody levels as well as on autoantibody levels shows a high degree of diversity (Table 1). In a recent study, only 11 out of 32 SLE patients with IgG hypergammaglobulinemia before treatment showed reduced IgG-levels after 12 months of treatment (144). Likewise, a reduction in anti-double-stranded DNA levels was incomplete, with high inter-individual variety and differences between antibody subclasses (145-148). Despite homogenous 
B cell depletion rates in MS of over 90 and 95\% in spinal fluid and in the periphery, respectively, the disease outcome showed great variation (104, 149-151). Interestingly, RTX has even been found to worsen the clinical outcome of MS (104).

These variable results might be not be surprising in the light of the finding that $\mathrm{B}$ lineage cells play multiple pro-and anti-inflammatory roles in experimental autoimmune encephalomyelitis (EAE), a murine model of MS. B cell-derived IL-6 has been shown to be crucial for the initiation of EAE, suggesting that $\mathrm{B}$ cells can promote MS pathogenesis through the production of this pro-inflammatory cytokine (93). However, there is an abundance of evidence that anti-inflammatory B cell subsets can also efficiently suppress CD4 T cells mediating neuroinflammation, and that these effects are mediated by B lineage-derived IL-10, TGF- $\beta$, and IL-35 $(98,152)$. These findings led to the concept of regulatory B cells (Bregs), which, however, have never been clearly defined. Recent results indicate that these IL- $10^{+} \mathrm{B}$ lineage cells have a plasmablast phenotype $(98,153)$. Similarly, investigations conducted by our group have identified plasmablasts/plasma cells as an important source of IL-10, capable of suppressing skin inflammation in a murine model of epidermolysis bullosa acquisita (EBA) (85). In EAE, B lineage-derived IL-6 and IL-10 were shown to have an impact on the induction and resolution of inflammation, respectively $(93,98,153)$. These findings may partly explain the heterogeneity of the clinical response to RTX observed in MS. Depending on the major role of B lineage cells as drivers or inhibitors of inflammation in individual patients, and possibly related to timing, RTX may be either beneficial or worse for the clinical course of MS.

\section{ALTERNATIVE B CELL TARGETING APPROACHES}

\section{Second Generation Anti-CD20 Antibodies}

The great clinical success of the chimeric antibody, RTX, has stimulated the development of the second generation anti-CD20 antibodies, ocrelizumab, obinutuzumab, veltuzumab, and ofatumumab (154). These second generation anti-CD20 antibodies are humanized or even fully human, exhibit improved effector functions, and compared with rituximab show greater potential in vitro. Due to these properties, they are expected to be more effective, to exhibit lower immunogenicity, and to be better tolerated. However, these expectations, which may be validated by head-to-head trials of these second generation anti-CD20 antibodies and RTX, have not been confirmed till date.

Ocrelizumab has recently been approved for the treatment of relapsing-remitting MS, and is the first approved treatment for primary progressive MS. In RA, however, ocrelizumab seems to have no benefit over current treatments, leading to a halt in the development of ocrelizumab for the treatment of RA (155).

Clinical trials exploring the use of obinutuzumab, veltuzumab, and ofatumumab in autoimmune disorders are at various stages of development and have been extensively reviewed by Du and colleagues (154). In general, it appears that the new anti-CD20 antibodies are effective against autoimmune diseases, against which RTX is also beneficial, but more studies are needed to evaluate their efficiency and long-term safety profiles in greater detail.

\section{Antibodies Targeting CD19}

Other B cell depleting reagents that promise a great potential for the treatment of autoimmune diseases are a series of reagents targeting CD19, which are currently under development. These include humanized antibodies, "bi-specific T cell engagers," and antibody-drug conjugates, such as inebilizumab, blinatumomab, and SAR3419, among several others $(156,157)$.

CD19 targeting therapeutics generally exhibit a broader target spectrum than anti-CD20 based reagents. CD19 is expressed very early in B cell development, being evident already on pro-B cells and on all later B cell stages, whereas CD20 is expressed later, starting at the immature B cell stage. Possibly of greater importance for the treatment of autoimmune diseases, in addition to all mature B cell subsets, CD19 is expressed on a significant proportion of plasmablasts and plasma cells, particularly outside the bone marrow $(64,114)$. Accordingly, CD19 targeting reagents have been reported to deplete pre-existing peripheral antibodysecreting cells, at least in humanized mouse models (158). Hence, CD19 targeting reagents might be not only suitable for treating $\mathrm{B}$ cell malignancies, but also exhibit great potential for therapeutic use in autoimmune diseases, particularly for those diseases with a strong involvement of pathogenic antibodies, e.g., SLE, pemphigus, and neuromyelitis optica.

\section{BAFF/APRIL Antagonists}

An alternative therapeutic strategy to target B cells is the blockade of B lineage survival factors, such as BAFF and its homolog APRIL and their receptors (159). Together, BAFF and APRIL along with their receptors form a complex system, which is very important for the survival of mature B cells and plasma cells. There are three receptors that bind BAFF and APRIL with different affinities. BAFF binds to BAFF-R, transmembrane activator and calcium modulator and cyclophilin ligand interactor, and B cell maturation protein. These three receptors are differentially expressed at various times during B cell ontogeny (160). Most BAFF circulates as a soluble active homo-trimer (161) that binds to BAFF-R and this interaction is required for survival of late transitional, $\mathrm{MZ}$, and mature naive B cells, all of which are depleted by BAFF-blockade $(162,163)$.

Several BAFF/APRIL targeting drugs are currently under development. The humanized anti-BAFF antibody belimumab has already been approved in the EU and the USA for the treatment of adult patients with active, autoantibody-positive, and SLE despite standard therapy. It is generally well tolerated with low rates of immunogenicity. Belimumab in combination with standard therapy reduces the overall disease activity and the incidence and severity of flares, has steroid-sparing effects, and can maintain disease control for at least 10 years (164). Interestingly, despite its clinical efficiency, belimumab only partly inhibits the production of IgG-autoantibodies. While some studies found no reduction of IgG-autoantibody levels following treatment with belimumab, others have reported a decline of $40-60 \%$ within 2-7 years of treatment (165-167). This is in accordance with the finding that belimumab depletes both naive and activated B cells, but not memory B cells $(165,167)$. 
Similar to what has been observed with RTX, B cell targeting by blockade of BAFF and APRIL using belimumab, tabalumab, or atacicept also shows greatly variable effects on the levels of autoantibodies and the clinical outcome of autoimmune diseases $(118,168-181)$, and of note, seem to have only limited effects on the production of (auto)antibodies (Table 2).

Generally, B cell targeting represents a powerful strategy for the treatment of autoimmune diseases. Its mechanism of action seems to be diverse and complex, and needs further elucidation.

\section{DIRECT TARGETING OF PLASMA CELLS BY BORTEZOMIB}

As originally shown by us and others, in mice, memory antibodies are secreted by long-lived plasma cells $(182,183)$. The notion that these cells can contribute to the production of autoantibodies but do not respond to current therapeutic approaches (57), has led to the search for novel plasma cell targeting agents.

The small molecule proteasome inhibitor bortezomib promotes plasma cell apoptosis and is approved for the treatment of multiple myeloma. Nearly a decade ago, Voll and colleagues reported that this drug could also be useful for the treatment of antibody-mediated autoimmune diseases. They demonstrated that bortezomib efficiently depletes both short-lived and long-lived plasma cells and protects mice with lupus-like disease from nephritis (70). Its efficacy was later proven in various models of antibody-mediated autoimmune diseases (184-186). There is now increasing evidence that bortezomib can also efficiently deplete autoantibodies in patients, resulting in the improvement of clinical symptoms, as has been described for refractory primary Sjögren's syndrome, refractory SLE, thrombotic thrombocytopenic purpura, and among others (9, 187-197). The potential development of severe side effects, such as peripheral neuropathies may limit the use of bortezomib in autoimmune diseases. However, its unique capacity to deplete antibody-producing plasma cells suggests that the safety and efficacy of bortezomib should be evaluated in clinical trials including more patients who are refractory to standard therapeutic approaches.

\section{INDUCTION OF ANTI-INFLAMMATORY B LINEAGE CELLS: A PROMISING THERAPEUTIC TREATMENT OPTION?}

IL- $10^{+} \mathrm{B}$ lineage cells have been known as potent suppressors of autoimmune inflammation for decades (198). Over the last decade, the expansion of IL- $10^{+} \mathrm{B}$ cells using various approaches has been shown to efficiently suppress both autoimmune and allergic inflammation in numerous models $(85,199,200)$. The first report that IL- $10^{+} \mathrm{B}$ cells exert a suppressive function was in 2002 by Fillatreau and colleagues (86), who showed that chimeric mice with a B cell specific IL-10 deficiency do not recover from EAE. Later, IL-10+ B cells were termed as Bregs or B10 cells. However, no surface marker or transcription factor unique to these cells has been identified to date. These cells are only functionally defined by their production of anti-inflammatory cytokines such as IL-10, and more recently IL-35, and the resulting suppression of inflammation and autoimmune diseases $(201,202)$.

\section{Phenotype and Origin of Human IL-10-Producing B Cells}

The combination of markers used to describe "regulatory B cells" in human and mice is controversial. The phenotypic identification of these B cells and their possible origin and development have been excellently reviewed elsewhere $(198,203)$. In humans, the ability to produce anti-inflammatory IL-10 has been reported in B cells at various stages of development: immature/ transitional B cells $\left(\mathrm{CD} 19^{+}\right.$CD $38^{\text {hi }}$ CD24 ${ }^{\text {hi }}$ ) (204), plasmablasts $\left(\mathrm{CD} 27^{\text {int }} \mathrm{CD} 38^{\text {hi }}\right)(153,205)$, and memory B cells $\left(\mathrm{CD} 19^{+} \mathrm{CD} 27^{+}\right)$ (206, 207). It is likely that IL- $10^{+} \mathrm{B}$ cells represent a transient stage with a functional program rather than a terminally differentiated stage, and that any B cell can acquire suppressive properties within a certain environment. Nevertheless, it is debatable if these cells arise from a single shared progenitor, from individual progenitors, or are induced under certain environmental stimuli $(198,203)$. Interestingly, in this context autocrine IL-10 can promote human IL- $10^{+} \mathrm{B}$ cells to differentiate into IgG- and IgM-secreting plasma cells (208).

\section{IL-10-Producing B Cells in Patients Suffering from Autoimmune Diseases}

The first report describing human IL-10-producing B lineage cells in autoimmune diseases was in 2010 by Iwata et al. (207), who described abnormally high frequencies of peripheral IL-10+ $\mathrm{B}$ cells in various autoimmune diseases, such as SLE, RA, MS, Sjögren's syndrome, and blistering skin diseases. An increase in the number of blood IL- $10^{+} \mathrm{CD} 19^{+} \mathrm{CD} 24^{\text {hi }} \mathrm{CD} 38^{\text {hi }}$ cells was also found in PV patients, but these B cells were functionally unable to suppress Th1 immune responses (209). By contrast, several studies on RA (206, 210-212), SLE (204), systemic sclerosis (SSc) $(213,214)$, and MS (215-217) patients have shown a reduced number of peripheral IL-10-producing B cells compared with that in the controls. This was often accompanied by an impaired suppressive capacity of CD4 T cells. An overview describing the modulation of human IL-10-producing B lineage cells in different autoimmune diseases has been provided by Miyagaki et al. (218).

\section{IL-10-Producing B Cell Dynamics Following B Cell Targeting Therapy}

In myasthenia gravis, depletion of B cells with RTX showed that IL-10+ $\mathrm{B}$ cells can be found to have repopulated in the periphery after several months (219). Immunosuppressive treatments, TNF-therapy, and BAFF-blockade in RA (206), SSc (213), and experimental diabetes mellitus type 1 (220), respectively, have shown that IL-10-producing $B$ lineage cells enrich after treatment and that their frequency is even higher than before treatment. In relapsing-remitting MS, the frequencies of $\mathrm{IL}-10^{+} \mathrm{CD} 19^{+} \mathrm{B}$ cells were significantly reduced in patients experiencing a relapse compared with that in patients in remission (217), indicating that the clinical outcome of the disease also depends on the availability of IL-10-producing B cells.

Moreover, a "good responder" to RTX in myasthenia gravis showed a rapid repopulation of $\mathrm{CD} 19^{+} \mathrm{IL}-10^{+} \mathrm{B}$ cells after 
TABLE 2 | Efficacy of belimumab, tabalumab, and atacicept.

\begin{tabular}{|c|c|c|c|c|c|c|c|c|c|c|}
\hline & & \multicolumn{3}{|c|}{ RA } & \multicolumn{4}{|c|}{ SLE } & \multirow{2}{*}{$\begin{array}{l}\text { SS } \\
\text { Belimumab }\end{array}$} & \multirow{2}{*}{$\begin{array}{l}\text { MS } \\
\text { Atacicept }\end{array}$} \\
\hline & & Atacicept & Belimumab & Tabalumab & Atacicept & Belimumab & Blisibimod & Tabalumab & & \\
\hline \multicolumn{2}{|l|}{ Patient no. } & 311 & 415 & 1,041 & $47 / 6$ & 1,353 & 547 & 1,124 & 30 & 255 \\
\hline \multicolumn{2}{|l|}{ Duration } & 38 weeks & 24/48 weeks & 52 weeks & 9/52 weeks & $52-76$ weeks & 24 weeks & 52 weeks & 52 weeks & 36 weeks \\
\hline $\begin{array}{l}\text { Clinical } \\
\text { improvement }\end{array}$ & $\begin{array}{l}\text { Partial } \\
\text { Complete } \\
\text { No }\end{array}$ & $\begin{array}{l}- \\
- \\
A C R 20\end{array}$ & $\begin{array}{l}\text { ACR20:in } 41 \% \\
- \\
\text { ACR50+70 }\end{array}$ & $\begin{array}{l}\text { ACR20/50/70:in } \\
\text { 70/36/13\% } \\
- \\
-\end{array}$ & $\begin{array}{l}\text { in } 22.2 \% \\
\text { in } 44.5 \% \\
\text { worse in } 33 \% \\
\text { stopped }\end{array}$ & $\begin{array}{l}\text { SELENA-SLEDAI/ } \\
\text { BILAG:in 46.5/58.6\% } \\
- \\
-\end{array}$ & $\begin{array}{l}\text { Proteinurea:reduced } \\
- \\
-\end{array}$ & $\begin{array}{l}\text { SRI-4:in 49.2\% } \\
- \\
\text { secondary } \\
\text { end point }\end{array}$ & $\begin{array}{l}\text { EULAR:in } \\
86.7 \% \\
- \\
-\end{array}$ & $\begin{array}{l}- \\
- \\
\text { Failed and } \\
\text { even worse }\end{array}$ \\
\hline \multicolumn{2}{|l|}{$\begin{array}{l}\text { B cell depletion } \\
\text { efficacy in } \\
\text { periphery }\end{array}$} & $\begin{array}{l}\text { Circulating mature } \\
\mathrm{B} \text { and plasma cells } \\
\text { reduced }\end{array}$ & $\begin{array}{l}\text { B cell depletion } \\
16-48 \% \text {; no depletion } \\
\text { of memory B cells } \\
\text { and plasma cells }\end{array}$ & $\begin{array}{l}\text { B cell reduction by } \\
18-40 \% \text {; no depletion } \\
\text { of memory B cells }\end{array}$ & $\begin{array}{l}\text { Reduction by } \\
60 \% \text {; plasma cells } \\
\text { depleted }\end{array}$ & Reduction by $55.7 \%$ & Significant reduction & $\begin{array}{l}\text { Significant } \\
\text { reduction }\end{array}$ & $\begin{array}{l}\text { Significant } \\
\text { reduction }\end{array}$ & Significant reduction \\
\hline \multicolumn{2}{|l|}{$\begin{array}{l}\text { Autoantibody } \\
\text { involvement }\end{array}$} & $\begin{array}{l}\text { RF but not anti-CCP } \\
\text { levels reduced }\end{array}$ & $\begin{array}{l}\text { Reduction of RF by } \\
30 \%\end{array}$ & CRP reduced & & $\begin{array}{l}\text { Reduction of anti- } \\
\text { dsDNA aab by } 44-49 \%\end{array}$ & $\begin{array}{l}\text { Anti-dsDNA } \\
\text { decreasedC3 } \\
\text { increased }\end{array}$ & $\begin{array}{l}\text { Anti-dsDNA } \\
\text { aab significantly } \\
\text { decreased }\end{array}$ & \multicolumn{2}{|l|}{$\begin{array}{l}\text { Reduction of } \\
\text { RF by } 30 \%\end{array}$} \\
\hline Remark & & $\begin{array}{l}\text { Serum IgA+M } \\
\text { (by } 19.4 \% \text { ) and } \\
\text { IgG (by } 8.6 \% \text { ) } \\
\text { modestly reduced }\end{array}$ & $\begin{array}{l}\text { Moderate change } \\
\text { of total Ig; better } \\
\text { response in RF+ } \\
\text { or ACPA+ patients }\end{array}$ & $\begin{array}{l}\text { Total serum Ig } \\
\text { decline by } 11 \% \\
\text { Phase III study in } \\
\text { RA terminated }\end{array}$ & & $\begin{array}{l}\text { Seropositive and } \\
\text { highly diseased } \\
\text { patients respond better; } \\
\text { total serum Ig modestly } \\
\text { reduced by } 16 \%\end{array}$ & & $\begin{array}{l}\mathrm{C} 3+\mathrm{C} 4 \\
\text { increased; total } \\
\text { serum Ig reduced; } \\
\text { development was } \\
\text { stopped }\end{array}$ & $\begin{array}{l}\text { Total lg not } \\
\text { changed }\end{array}$ & $\begin{array}{l}\text { Severe adverse } \\
\text { events; higher } \\
\text { relapse rate in treated } \\
\text { group compared to } \\
\text { controls }\end{array}$ \\
\hline References & & $\begin{array}{l}\text { Genovese et al. (170); } \\
\text { van Vollenhoven } \\
\text { et al. (171) }\end{array}$ & Stohl et al. (181) & $\begin{array}{l}\text { Smolen et al. (168); } \\
\text { Greenwald et al. (169) }\end{array}$ & $\begin{array}{l}\text { Dall'Era et al. } \\
\text { (176); Lenert et al. } \\
\text { (177); Ginzler } \\
\text { et al. (178) }\end{array}$ & $\begin{array}{l}\text { Navarra et al. (172); } \\
\text { Furie et al. (173) }\end{array}$ & Furie et al. (175) & Merrill et al. (174) & $\begin{array}{l}\text { Mariette } \\
\text { et al. (179) }\end{array}$ & Kappos et al. (180) \\
\hline
\end{tabular}

RA, rheumatoid arthritis; SLE, systemic lupus erythematosus; SS, Sjörgen's syndrome; MS, multiple sclerosis; ACR, American College of Rheumatology Criteria, standard criteria to measure the effectiveness of arthritis treatments in clinical trials for rheumatoid arthritis, 20/50/70 refers to the improvement in tender or swollen joint counts as a percentage; CCP, cyclic citrullinated peptides; RF, rheumatoid factor; MMF, methyl mofetil; std, standard therapy; BILAG, British Isles Lupus Activity Group, organ-specific 86-question assessment based on the principle of the clinical intent to treat; SELENA, Safety of Estrogens in Systemic Lupus Erythematosus National Assessment; SLEDAI, SLE Disease Activity Index, a list of 24 items (16 clinical items, including seizure, psychosis, organic brain syndrome, visual disturbance, other neurological problems, hair loss, new rash, muscle weakness, arthritis, blood vessel inflammation, mouth sores, chest pain that worsens with deep breathing, and manifestations of pleurisy and/or pericarditis and fever, and eight laboratory results, including urinalysis testing, blood complement levels, increased anti-DNA antibody levels, low platelet count, and low white blood cell count); EDSS, Expanded Disability Status Scale is a method of quantifying disability in multiple sclerosis and monitoring changes in the level of disability; aab, autoantibodies; C3 + 4, Complement factors 3 and 4; ACPA, Anti-citrullinated peptide/protein antibodies; CRP, C-reactive protein; SRI-4, Systemic Lupus Erythematosus Responder Index for 4-point reduction due to SLEDAl; EULAR SS, The European League Against Rheumatism for Sjörgen's Syndrome; Ig, immunoglobulins; dsDNA, double-stranded DNA. 
from 8 to 9 months compared with a "non-responder," where repopulation was delayed (219). This shows that the kinetics of the IL- $10^{+} \mathrm{B}$ cell repopulation is related to the responsiveness to RTX. Similarly, Colliou et al. (221) have shown that RTX-treated PV patients in complete remission had fourfold higher numbers of IL- $10^{+} \mathrm{CD} 19^{+} \mathrm{B}$ cells compared with patients in incomplete remission. In SLE patients responding well to RTX treatment, IL- $10^{+}$CD24 $4^{\text {hi }}$ CD $38^{\text {hi }}$ B cells were found to repopulate and exhibited a restored suppressive function compared to nonresponders (222).

Differences in IL-10-producing B cells in individual patients and types of autoimmune diseases could explain the differential outcome and benefit of B cell specific therapies. For example, in SLE and lupus nephritis, pan B cell therapies, such as RTX, show only moderate or even no benefit, despite the significant role of B cells in this disease $(145,223)$. The depletion of antiinflammatory B cells could contribute to this unexpected result. Very few studies to date have included an analysis of the kinetics and function of IL-10-producing B cells after B cell depleting therapy. To better understand the individual clinical outcome of the patients and the differences between certain autoimmune diseases treated with the same B cell targeting agent, it would be of great benefit to include an analysis of IL- $10^{+} \mathrm{B}$ lineage cells in further studies.

\section{Challenges Hampering the Development of IL-10+ $B$ Cell-Based Therapies}

Restoring the regulatory capacity and the number of IL- $10^{+}$ $\mathrm{B}$ cells is a promising therapeutic goal for the treatment of autoimmune diseases. However, currently two unsolved problems hamper the development of a therapy based on IL-10+ $\mathrm{B}$ cells. First, the methods used to generate IL $-10^{+} \mathrm{B}$ cells for therapeutic approaches are not suitable for a clinical setting. Second, the identity and phenotype of IL- $10^{+}$B cells remain uncertain. Nevertheless, recent progress has been made with respect to both issues. Giacomini et al. (224) have shown that stimulation of peripheral blood mononuclear cells (PBMCs) from MS patients with thymosin- $\alpha 1$ (T $\alpha 1)$ increases IL-10 and IL-35 secretion and expands transitional- and plasmablast-like B cell populations. Upon exposure to pro-inflammatory cytokines, such as IL-21, IL-6, and IL-1 $\beta$, an expansion of IL-10+ $B$ cell population has been observed. In RA patients, IL-21 increases the number of IL-10-producing B cells in the memory compartment and induces IL- $10^{+}$plasmablasts (206), whereas in mice, gut microbiota-derived IL- $1 \beta$ and IL- 6 promote the formation of various IL- $10^{+} \mathrm{B}$ lineage cells in the spleen and lymph nodes (225). By contrast, the anti-inflammatory cytokine IL-35 can also induce human B cells to produce IL-10 and IL-35 (226). Nevertheless, inducing anti-inflammatory B cells in vivo via inflammatory cytokines bears the risk of undesirable pathogenic side effects by also activating other effector cell types. If not expanded in vivo, IL-10+ $\mathrm{B}$ cells could be also induced from patient PBMCs in vitro and transferred back. Here, the questions of the amount of B cells required to improve clinical symptoms and the stability of the IL- $10^{+}$phenotype and function arise. The difficulties and potential of these therapies were recently discussed by Mauri and Menon (227).

\section{Induction of IL-10-Producing Plasma Cells/Plasmablasts: Potential as a Novel Treatment Option}

Progress has been made in defining the identity of IL- $10^{+} \mathrm{B}$ cells that could be used to develop a novel therapeutic strategy. During the last decade, several phenotypically distinct murine B cell subsets have been described that produce IL-10 upon in vitro stimulation, which was able to limit autoimmune diseases (198). These cells include $\mathrm{B}$ cells with a $\mathrm{CD} 5^{+} \mathrm{CD} 1 \mathrm{~d}^{\text {hi }}$ phenotype (B10) (228), CD5 ${ }^{+}$B cells (B1-a) (229), transitional type 2-MZ precursors (230), and MZ B cells (231).

Of note, the surface markers used to characterize the identity of the IL- $10^{+} \mathrm{B}$ cells change following activation and might be not suitable to define a specific B cell subtype under inflammatory conditions. Interestingly in this context, it has been shown that "B10" cells upregulate the expression of the transcription factors Blimp1 and IRF4 while downregulating that of Pax5, suggesting that these cells undergo plasma cell differentiation. Moreover, upon transfer into recipient mice, "B10" cells become antibody-secreting cells (232). More recently, CD138 ${ }^{\text {hi }}$ plasmablasts in murine spleen (98) or lymph nodes (153) were described as the major producer of antiinflammatory IL-10 and IL-35 in vivo with the ability to limit EAE. In accordance with these findings, we found that IL- $10^{+}$plasma cells exhibit profound anti-inflammatory activities in a model of $\mathrm{EBA}$, a rare autoimmune skin disease (85). These cells induce IL-10 expression but reduce IFN- $\gamma$ production in CD4 T cells, promote IL-10 production by $\mathrm{CD}^{+} / \mathrm{Foxp}^{+}$Tregs and suppress neutrophil functions. Hence, IL- $10^{+}$plasmablasts/plasma cells represent an important anti-inflammatory B cell subtype.

Identification of the identity of IL- $10^{+} \mathrm{B}$ lineage cells may help to develop a novel method to induce these cells in a therapeutic setting. Stimulation of B cells with CpG-oligonucleotides induces both plasma cell differentiation and IL-10 expression. Accordingly, experimental induction of IL- $10^{+} \mathrm{B}$ lineage cells by adaptive transfer of CpG-stimulated $\mathrm{B}$ cells has recently been shown to suppress ongoing EAE inflammation in a therapeutic setting (200). This approach may open a novel perspective for the treatment of inflammatory autoimmune diseases.

\section{CONCLUDING REMARKS}

The success of current B cell targeting therapies emphasizes the important roles B cells play in the pathogenesis of autoimmune diseases. There is overwhelming evidence from animal models indicating that $\mathrm{B}$ lineage cells exhibit multiple powerful pro- and anti-inflammatory capacities. The current experience with B cell targeting therapies suggests that these findings also hold true in the clinic. Hence, therapies that specifically deplete pathogenic B cells and plasma cells, or generate immunosuppressive B cells/plasma cells could hold great potential for the treatment of autoimmune diseases. In an optimal setting, the therapy would be tailored to the individual patient based on his/her predicted needs, benefits, and risks.

\section{AUTHOR CONTRIBUTIONS}

$\mathrm{KH}, \mathrm{A}-\mathrm{KC}$, and $\mathrm{RM}$ contributed to reviewing the current literature and writing of the manuscript. 


\section{FUNDING}

$\mathrm{KH}$ was supported by the Research Training Group 1727 "Modulation of Autoimmunity" (GRK 1727). A-KC was founded

\section{REFERENCES}

1. Manz RA, Hauser AE, Hiepe F, Radbruch A. Maintenance of serum antibody levels. Annu Rev Immunol (2005) 23:367-86. doi:10.1146/annurev. immunol.23.021704.115723

2. Yan SX, Deng XM, Wang QT, Sun XJ, Wei W. Prednisone treatment inhibits the differentiation of B lymphocytes into plasma cells in MRL/MpSlac-lpr mice. Acta Pharmacol Sin (2015) 36:1367-76. doi:10.1038/aps.2015.76

3. Cupps TR, Gerrard TL, Falkoff RJ, Whalen G, Fauci AS. Effects of in vitro corticosteroids on B cell activation, proliferation, and differentiation. J Clin Invest (1985) 75:754-61. doi:10.1172/JCI111757

4. Zhu LP, Cupps TR, Whalen G, Fauci AS. Selective effects of cyclophosphamide therapy on activation, proliferation, and differentiation of human B cells. J Clin Invest (1987) 79:1082-90. doi:10.1172/JCI112922

5. Glaesener S, Quach TD, Onken N, Weller-Heinemann F, Dressler F, Huppertz HI, et al. Distinct effects of methotrexate and etanercept on the B cell compartment in patients with juvenile idiopathic arthritis. Arthritis Rheumatol (2014) 66:2590-600. doi:10.1002/art.38736

6. Liu Z, Davidson A. BAFF inhibition: a new class of drugs for the treatment of autoimmunity. Exp Cell Res (2011) 317:1270-7. doi:10.1016/j.yexcr. 2011.02.005

7. Marshall MJE, Stopforth RJ, Cragg MS. Therapeutic antibodies: what have we learnt from targeting CD20 and where are we going? Front Immunol (2017) 8:1245. doi:10.3389/fimmu.2017.01245

8. Zhao Q, Chen X, Li J, Jiang J, Li M, Zhong W, et al. Pharmacokinetics, pharmacodynamics and preliminary observations for clinical activity and safety of multiple doses of human mouse chimeric anti-CD22 monoclonal antibody (SM03) in Chinese patients with systemic lupus erythematosus. Clin Drug Investig (2016) 36:889-902. doi:10.1007/s40261-016-0426-7

9. Alexander T, Sarfert R, Klotsche J, Kuhl AA, Rubbert-Roth A, Lorenz HM, et al. The proteasome inhibitior bortezomib depletes plasma cells and ameliorates clinical manifestations of refractory systemic lupus erythematosus. Ann Rheum Dis (2015) 74:1474-8. doi:10.1136/annrheumdis-2014-206016

10. Emery P, Gottenberg JE, Rubbert-Roth A, Sarzi-Puttini P, Choquette D, Taboada VM, et al. Rituximab versus an alternative TNF inhibitor in patients with rheumatoid arthritis who failed to respond to a single previous TNF inhibitor: SWITCH-RA, a global, observational, comparative effectiveness study. Ann Rheum Dis (2015) 74:979-84. doi:10.1136/annrheumdis-2013203993

11. Emery P, Fleischmann R, Filipowicz-Sosnowska A, Schechtman J, Szczepanski L, Kavanaugh A, et al. The efficacy and safety of rituximab in patients with active rheumatoid arthritis despite methotrexate treatment: results of a phase IIB randomized, double-blind, placebo-controlled, dose-ranging trial. Arthritis Rheum (2006) 54:1390-400. doi:10.1002/art.21778

12. Moreno Torres I, Garcia-Merino A. Anti-CD20 monoclonal antibodies in multiple sclerosis. Expert Rev Neurother (2017) 17:359-71. doi:10.1080/ 14737175.2017.1245616

13. Allman D, Pillai S. Peripheral B cell subsets. Curr Opin Immunol (2008) 20:149-57. doi:10.1016/j.coi.2008.03.014

14. Ehrenstein MR, Notley CA. The importance of natural IgM: scavenger, protector and regulator. Nat Rev Immunol (2010) 10:778-86. doi:10.1038/ nri2849

15. Gronwall C, Vas J, Silverman GJ. Protective roles of natural IgM antibodies. Front Immunol (2012) 3:66. doi:10.3389/fimmu.2012.00066

16. Holodick NE, Zeumer L, Rothstein TL, Morel L. Expansion of B-1a cells with germline heavy chain sequence in lupus mice. Front Immunol (2016) 7:108. doi:10.3389/fimmu.2016.00108

17. Viau M, Zouali M. B-lymphocytes, innate immunity, and autoimmunity. Clin Immunol (2005) 114:17-26. doi:10.1016/j.clim.2004.08.019

18. Hardy RR, Li YS, Allman D, Asano M, Gui M, Hayakawa K. B-cell commitment, development and selection. Immunol Rev (2000) 175:23-32. doi:10.1111/j.1600-065X.2000.imr017517.x by the Clinical Research Unit 303 "Pemphigoid Diseases Molecular Pathways and their Therapeutic Potential" (CRU303). RM was supported by the Excellence Cluster "Inflammation at Interfaces" (EXC 306/2).

19. King LB, Monroe JG. Immunobiology of the immature B cell: plasticity in the B-cell antigen receptor-induced response fine tunes negative selection. Immunol Rev (2000) 176:86-104. doi:10.1034/j.1600-065X.2000. 00609.x

20. George J, Claflin L. Selection of B cell clones and memory B cells. Semin Immunol (1992) 4:11-7.

21. Cyster JG. Chemokines and cell migration in secondary lymphoid organs. Science (1999) 286:2098-102. doi:10.1126/science.286.5447.2098

22. Lang K, Pruss H. Frequencies of neuronal autoantibodies in healthy controls: estimation of disease specificity. Neurol Neuroimmunol Neuroinflamm (2017) 4:e386. doi:10.1212/NXI.0000000000000386

23. Pisetsky DS. Antinuclear antibody testing - misunderstood or misbegotten? Nat Rev Rheumatol (2017) 13:495-502. doi:10.1038/nrrheum.2017.74

24. Perez-Andres M, Paiva B, Nieto WG, Caraux A, Schmitz A, Almeida J, et al. Human peripheral blood B-cell compartments: a crossroad in B-cell traffic. Cytometry B Clin Cytom (2010) 78(Suppl 1):S47-60. doi:10.1002/cyto. b. 20547

25. Nitschke L, Floyd H, Ferguson DJ, Crocker PR. Identification of CD22 ligands on bone marrow sinusoidal endothelium implicated in CD22-dependent homing of recirculating B cells. J Exp Med (1999) 189:1513-8. doi:10.1084/ jem.189.9.1513

26. Geherin SA, Fintushel SR, Lee MH, Wilson RP, Patel RT, Alt C, et al. The skin, a novel niche for recirculating B cells. J Immunol (2012) 188:6027-35. doi:10.4049/jimmunol.1102639

27. Dufaud CR, McHeyzer-Williams LJ, McHeyzer-Williams MG. Deconstructing the germinal center, one cell at a time. Curr Opin Immunol (2017) 45:112-8. doi:10.1016/j.coi.2017.03.007

28. Ribatti D. The discovery of plasma cells: an historical note. Immunol Lett (2017) 188:64-7. doi:10.1016/j.imlet.2017.06.006

29. Luo Y, Yoshihara A, Oda K, Ishido Y, Suzuki K. Excessive cytosolic DNA fragments as a potential trigger of Graves' disease: an encrypted message sent by animal models. Front Endocrinol (2016) 7:144. doi:10.3389/fendo. 2016.00144

30. Klein U, Goossens T, Fischer M, Kanzler H, Braeuninger A, Rajewsky K, et al. Somatic hypermutation in normal and transformed human B cells. Immunol Rev (1998) 162:261-80. doi:10.1111/j.1600-065X.1998.tb01447.x

31. Seifert M, Przekopowitz M, Taudien S, Lollies A, Ronge V, Drees B, et al. Functional capacities of human IgM memory B cells in early inflammatory responses and secondary germinal center reactions. Proc Natl Acad Sci US A (2015) 112:E546-55. doi:10.1073/pnas.1416276112

32. Wienands J, Engels N. Control of memory B cell responses by extrinsic and intrinsic mechanisms. Immunol Lett (2016) 178:27-30. doi:10.1016/j. imlet.2016.05.010

33. Vitetta ES, Berton MT, Burger C, Kepron M, Lee WT, Yin XM. Memory B and T cells. Annu Rev Immunol (1991) 9:193-217. doi:10.1146/annurev. iy.09.040191.001205

34. Arpin C, de Bouteiller O, Razanajaona D, Briere F, Banchereau J, Lebecque S, et al. Human peripheral B cell development. sIgM-IgD+CD38+ hypermutated germinal center centroblasts preferentially express Ig lambda light chain and have undergone mu-to-delta switch. Ann N Y Acad Sci (1997) 815:193-8. doi:10.1111/j.1749-6632.1997.tb52060.x

35. Tangye SG, Avery DT, Deenick EK, Hodgkin PD. Intrinsic differences in the proliferation of naive and memory human B cells as a mechanism for enhanced secondary immune responses. JImmunol (2003) 170:686-94. doi:10.4049/jimmunol.170.2.686

36. Deenick EK, Avery DT, Chan A, Berglund LJ, Ives ML, Moens L, et al. Naive and memory human B cells have distinct requirements for STAT3 activation to differentiate into antibody-secreting plasma cells. JExp Med (2013) 210:2739-53. doi:10.1084/jem.20130323

37. Feldhahn N, Schwering I, Lee S, Wartenberg M, Klein F, Wang H, et al. Silencing of B cell receptor signals in human naive B cells. J Exp Med (2002) 196:1291-305. doi:10.1084/jem.20020881 
38. Klein U, Tu Y, Stolovitzky GA, Keller JL, Haddad J Jr, Miljkovic V, et al. Transcriptional analysis of the B cell germinal center reaction. Proc Natl Acad Sci U S A (2003) 100:2639-44. doi:10.1073/pnas.0437996100

39. Nowosad CR, Spillane KM, Tolar P. Germinal center B cells recognize antigen through a specialized immune synapse architecture. Nat Immunol (2016) 17:870-7. doi:10.1038/ni.3458

40. Sacquin A, Gador M, Fazilleau N. The strength of BCR signaling shapes terminal development of follicular helper $\mathrm{T}$ cells in mice. Eur J Immunol (2017) 47:1295-304. doi:10.1002/eji.201746952

41. Agematsu K, Nagumo H, Oguchi Y, Nakazawa T, Fukushima K, Yasui K, et al. Generation of plasma cells from peripheral blood memory B cells: synergistic effect of interleukin-10 and CD27/CD70 interaction. Blood (1998) 91: $173-80$.

42. Maurer D, Holter W, Majdic O, Fischer GF, Knapp W. CD27 expression by a distinct subpopulation of human B lymphocytes. Eur J Immunol (1990) 20:2679-84. doi:10.1002/eji.1830201223

43. Bar-Or A, Oliveira EM, Anderson DE, Krieger JI, Duddy M, O'Connor KC, et al. Immunological memory: contribution of memory B cells expressing costimulatory molecules in the resting state. J Immunol (2001) 167:5669-77. doi:10.4049/jimmunol.167.10.5669

44. Liu YJ, Barthelemy C, de Bouteiller O, Arpin C, Durand I, Banchereau J. Memory B cells from human tonsils colonize mucosal epithelium and directly present antigen to $\mathrm{T}$ cells by rapid up-regulation of B7-1 and B7-2. Immunity (1995) 2:239-48. doi:10.1016/1074-7613(95)90048-9

45. Roy MP, Kim CH, Butcher EC. Cytokine control of memory B cell homing machinery.J Immunol(2002) 169:1676-82. doi:10.4049/jimmunol.169.4.1676

46. Muehlinghaus G, Cigliano L, Huehn S, Peddinghaus A, Leyendeckers H, Hauser AE, et al. Regulation of CXCR3 and CXCR4 expression during terminal differentiation of memory B cells into plasma cells. Blood (2005) 105:3965-71. doi:10.1182/blood-2004-08-2992

47. Ubillos I, Campo JJ, Requena P, Ome-Kaius M, Hanieh S, Rose H, et al. Chronic exposure to malaria is associated with inhibitory and activation markers on atypical memory B cells and marginal zone-like B cells. Front Immunol (2017) 8:966. doi:10.3389/fimmu.2017.00966

48. Manz RA, Moser K, Burmester GR, Radbruch A, Hiepe F. Immunological memory stabilizing autoreactivity. Curr Top Microbiol Immunol (2006) 305:241-57.

49. Reddy V, Klein C, Isenberg DA, Glennie MJ, Cambridge G, Cragg MS, et al. Obinutuzumab induces superior B-cell cytotoxicity to rituximab in rheumatoid arthritis and systemic lupus erythematosus patient samples. Rheumatology (Oxford) (2017) 56:1227-37. doi:10.1093/rheumatology/ kex067

50. Muto K, Matsui N, Unai Y, Sakai W, Haji S, Udaka K, et al. Memory B cell resurgence requires repeated rituximab in myasthenia gravis. Neuromuscul Disord (2017) 27:918-22. doi:10.1016/j.nmd.2017.06.012

51. Cho A, Bradley B, Kauffman R, Priyamvada L, Kovalenkov Y, Feldman R, et al. Robust memory responses against influenza vaccination in pemphigus patients previously treated with rituximab. JCI Insight (2017) 2:e93222. doi:10.1172/jci.insight.93222

52. Budeus B, Schweigle de Reynoso S, Przekopowitz M, Hoffmann D, Seifert M, Kuppers R. Complexity of the human memory B-cell compartment is determined by the versatility of clonal diversification in germinal centers. Proc Natl Acad Sci U S A (2015) 112:E5281-9. doi:10.1073/pnas.1511270112

53. Dogan I, Bertocci B, Vilmont V, Delbos F, Megret J, Storck S, et al. Multiple layers of B cell memory with different effector functions. Nat Immunol (2009) 10:1292-9. doi:10.1038/ni.1814

54. Odendahl M, Mei H, Hoyer BF, Jacobi AM, Hansen A, Muehlinghaus G, et al. Generation of migratory antigen-specific plasma blasts and mobilization of resident plasma cells in a secondary immune response. Blood (2005) 105:1614-21. doi:10.1182/blood-2004-07-2507

55. Young KH, Chan WC, Fu K, Iqbal J, Sanger WG, Ratashak A, et al. Mantle cell lymphoma with plasma cell differentiation. Am J Surg Pathol (2006) 30:954-61. doi:10.1097/00000478-200608000-00004

56. Hiepe F, Alexander T, Voll RE. [Plasma cells]. Z Rheumatol (2015) 74:20-5. doi:10.1007/s00393-014-1438-4

57. Hoyer BF, Moser K, Hauser AE, Peddinghaus A, Voigt C, Eilat D, et al. Shortlived plasmablasts and long-lived plasma cells contribute to chronic humoral autoimmunity in NZB/W mice. J Exp Med (2004) 199:1577-84. doi:10.1084/ jem. 20040168
58. Hargreaves DC, Hyman PL, Lu TT, Ngo VN, Bidgol A, Suzuki G, et al. A coordinated change in chemokine responsiveness guides plasma cell movements. J Exp Med (2001) 194:45-56. doi:10.1084/jem.194.1.45

59. Kabashima K, Haynes NM, Xu Y, Nutt SL, Allende ML, Proia RL, et al. Plasma cell S1P1 expression determines secondary lymphoid organ retention versus bone marrow tropism. J Exp Med (2006) 203:2683-90. doi:10.1084/ jem.20061289

60. Moser K, Tokoyoda K, Radbruch A, MacLennan I, Manz RA. Stromal niches, plasma cell differentiation and survival. Curr Opin Immunol (2006) 18:265-70. doi:10.1016/j.coi.2006.03.004

61. Quiding-Jarbrink M, Nordstrom I, Granstrom G, Kilander A, Jertborn M, Butcher EC, et al. Differential expression of tissue-specific adhesion molecules on human circulating antibody-forming cells after systemic, enteric, and nasal immunizations. A molecular basis for the compartmentalization of effector B cell responses. J Clin Invest (1997) 99:1281-6. doi:10.1172/JCI119286

62. Quiding-Järbrink M, Lakew M, Nordström I, Banchereau J, Butcher E, Holmgren J, et al. Human circulating specific antibody-forming cells after systemic and mucosal immunizations: differential homing commitments and cell surface differentiation markers. Eur J Immunol (1995) 25:322-7. doi:10.1002/eji.1830250203

63. Ferraro AJ, Drayson MT, Savage CO, MacLennan IC. Levels of autoantibodies, unlike antibodies to all extrinsic antigen groups, fall following $\mathrm{B}$ cell depletion with Rituximab. Eur J Immunol (2008) 38:292-8. doi:10.1002/ eji.200737557

64. Arce S, Luger E, Muehlinghaus G, Cassese G, Hauser A, Horst A, et al. CD38 low IgG-secreting cells are precursors of various CD38 high-expressing plasma cell populations. JLeukoc Biol (2004) 75:1022-8. doi:10.1189/ jlb.0603279

65. Rodriguez-Bayona B, Ramos-Amaya A, Bernal J, Campos-Caro A, Brieva JA. Cutting edge: IL-21 derived from human follicular helper T cells acts as a survival factor for secondary lymphoid organ, but not for bone marrow, plasma cells. J Immunol (2012) 188:1578-81. doi:10.4049/jimmunol.1102786

66. Kehrl JH, Riva A, Wilson GL, Thevenin C. Molecular mechanisms regulating CD19, CD20 and CD22 gene expression. Immunol Today (1994) 15:432-6. doi:10.1016/0167-5699(94)90273-9

67. Mei HE, Schmidt S, Dorner T. Rationale of anti-CD19 immunotherapy: an option to target autoreactive plasma cells in autoimmunity. Arthritis Res Ther (2012) 14(Suppl 5):S1. doi:10.1186/ar3909

68. Leandro MJ. B-cell subpopulations in humans and their differential susceptibility to depletion with anti-CD20 monoclonal antibodies. Arthritis Res Ther (2013) 15(Suppl 1):S3. doi:10.1186/ar3908

69. Fabris M, De Vita S, Blasone N, Visentini D, Pezzarini E, Pontarini E, et al. Serum levels of anti-CCP antibodies, anti-MCV antibodies and RF IgA in the follow-up of patients with rheumatoid arthritis treated with rituximab. Auto Immun Highlights (2010) 1:87-94. doi:10.1007/s13317-010-0013-5

70. Neubert K, Meister S, Moser K, Weisel F, Maseda D, Amann K, et al. The proteasome inhibitor bortezomib depletes plasma cells and protects mice with lupus-like disease from nephritis. Nat Med (2008) 14:748-55. doi:10.1038/ nm1763

71. Ludwig RJ, Vanhoorelbeke K, Leypoldt F, Kaya Z, Bieber K, McLachlan SM, et al. Mechanisms of autoantibody-induced pathology. Front Immunol (2017) 8:603. doi:10.3389/fimmu.2017.00603

72. Toriani-Terenzi C, Fagiolo E. IL-10 and the cytokine network in the pathogenesis of human autoimmune hemolytic anemia. Ann N Y Acad Sci (2005) 1051:29-44. doi:10.1196/annals.1361.044

73. Boi F, Pani F, Mariotti S. Thyroid autoimmunity and thyroid cancer: review focused on cytological studies. Eur Thyroid J (2017) 6:178-86. doi:10.1159/000468928

74. Rose T, Dorner T. Drivers of the immunopathogenesis in systemic lupus erythematosus. Best Pract Res Clin Rheumatol (2017) 31:321-33. doi:10.1016/j. berh.2017.09.007

75. Frohlich E, Wahl R. Thyroid autoimmunity: role of anti-thyroid antibodies in thyroid and extra-thyroidal diseases. Front Immunol (2017) 8:521. doi:10.3389/fimmu.2017.00521

76. Strait RT, Posgai MT, Mahler A, Barasa N, Jacob CO, Kohl J, et al. IgG1 protects against renal disease in a mouse model of cryoglobulinaemia. Nature (2015) 517:501-4. doi:10.1038/nature13868

77. Nimmerjahn F, Ravetch JV. Fcgamma receptors as regulators of immune responses. Nat Rev Immunol (2008) 8:34-47. doi:10.1038/nri2206 
78. Oefner CM, Winkler A, Hess C, Lorenz AK, Holecska V, Huxdorf M, et al. Tolerance induction with $\mathrm{T}$ cell-dependent protein antigens induces regulatory sialylated IgGs. J Allergy Clin Immunol (2012) 129:1647-55.e13. doi:10.1016/j.jaci.2012.02.037

79. Karsten CM, Pandey MK, Figge J, Kilchenstein R, Taylor PR, Rosas M, et al. Anti-inflammatory activity of IgG1 mediated by Fc galactosylation and association of FcgammaRIIB and dectin-1. Nat Med (2012) 18:1401-6. doi: $10.1038 / \mathrm{nm} .2862$

80. Anthony RM, Ravetch JV. A novel role for the IgG Fc glycan: the antiinflammatory activity of sialylated IgG Fcs. J Clin Immunol (2010) 30 (Suppl 1):S9-14. doi:10.1007/s10875-010-9405-6

81. Hess C, Winkler A, Lorenz AK, Holecska V, Blanchard V, Eiglmeier S, et al. T cell-independent B cell activation induces immunosuppressive sialylated IgG antibodies. J Clin Invest (2013) 123:3788-96. doi:10.1172/JCI65938

82. Pfeifle R, Rothe T, Ipseiz N, Scherer HU, Culemann S, Harre U, et al. Regulation of autoantibody activity by the IL-23-TH17 axis determines the onset of autoimmune disease. Nat Immunol (2017) 18:104-13. doi:10.1038/ ni.3579

83. Seeling M, Bruckner C, Nimmerjahn F. Differential antibody glycosylation in autoimmunity: sweet biomarker or modulator of disease activity? Nat Rev Rheumatol (2017) 13:621-30. doi:10.1038/nrrheum.2017.146

84. Claes N, Fraussen J, Stinissen P, Hupperts R, Somers V. B cells are multifunctional players in multiple sclerosis pathogenesis: insights from therapeutic interventions. Front Immunol (2015) 6:642. doi:10.3389/fimmu.2015.00642

85. Kulkarni U, Karsten CM, Kohler T, Hammerschmidt S, Bommert K, Tiburzy B, et al. IL-10 mediates plasmacytosis-associated immunodeficiency by inhibiting complement-mediated neutrophil migration. JAllergy Clin Immunol (2016) 137:1487-97.e6. doi:10.1016/j.jaci.2015.10.018

86. Fillatreau S, Sweenie CH, McGeachy MJ, Gray D, Anderton SM. B cells regulate autoimmunity by provision of IL-10. Nat Immunol (2002) 3:944-50. doi:10.1038/ni833

87. Crawford A, Macleod M, Schumacher T, Corlett L, Gray D. Primary T cell expansion and differentiation in vivo requires antigen presentation by $\mathrm{B}$ cells. J Immunol (2006) 176:3498-506. doi:10.4049/jimmunol.176.6.3498

88. Rodriguez-Pinto D, Moreno J. B cells can prime naive CD4+ T cells in vivo in the absence of other professional antigen-presenting cells in a CD154CD40-dependent manner. Eur J Immunol (2005) 35:1097-105. doi:10.1002/ eji.200425732

89. Secrist H, DeKruyff RH, Umetsu DT. Interleukin 4 production by CD4+ $\mathrm{T}$ cells from allergic individuals is modulated by antigen concentration and antigen-presenting cell type. J Exp Med (1995) 181:1081-9. doi:10.1084/ jem.181.3.1081

90. Krieger J, Jenis DM, Chesnut RW, Grey HM. Studies on the capacity of intact cells and purified Ia from different B cell sources to function in antigen presentation to T cells. J Immunol (1988) 140:388-94.

91. Bermejo DA, Jackson SW, Gorosito-Serran M, Acosta-Rodriguez EV, Amezcua-Vesely MC, Sather BD, et al. Trypanosoma cruzi trans-sialidase initiates a program independent of the transcription factors RORgammat and Ahr that leads to IL-17 production by activated B cells. Nat Immunol (2013) 14:514-22. doi:10.1038/ni.2569

92. Lino AC, Dorner T, Bar-Or A, Fillatreau S. Cytokine-producing B cells: a translational view on their roles in human and mouse autoimmune diseases. Immunol Rev (2016) 269:130-44. doi:10.1111/imr.12374

93. Barr TA, Shen P, Brown S, Lampropoulou V, Roch T, Lawrie S, et al. B cell depletion therapy ameliorates autoimmune disease through ablation of IL6-producing B cells. J Exp Med(2012) 209:1001-10. doi:10.1084/jem.20111675

94. Shen P, Fillatreau S. Antibody-independent functions of B cells: a focus on cytokines. Nat Rev Immunol (2015) 15:441-51. doi:10.1038/nri3857

95. Anderton SM, Fillatreau S. Activated B cells in autoimmune diseases: the case for a regulatory role. Nat Clin Pract Rheumatol (2008) 4:657-66. doi:10.1038/ ncprheum0950

96. Dang VD, Hilgenberg E, Ries S, Shen P, Fillatreau S. From the regulatory functions of $\mathrm{B}$ cells to the identification of cytokine-producing plasma cell subsets. Curr Opin Immunol (2014) 28:77-83. doi:10.1016/j.coi.2014. 02.009

97. Fillatreau S. B cells and their cytokine activities implications in human diseases. Clin Immunol (2017) 186:26-31. doi:10.1016/j.clim.2017.07.020

98. Shen P, Roch T, Lampropoulou V, O'Connor RA, Stervbo U, Hilgenberg E, et al. IL-35-producing $\mathrm{B}$ cells are critical regulators of immunity during autoimmune and infectious diseases. Nature (2014) 507:366-70. doi:10.1038/ nature 12979

99. Walshe CA, Beers SA, French RR, Chan CH, Johnson PW, Packham GK, et al. Induction of cytosolic calcium flux by CD20 is dependent upon B cell antigen receptor signaling. J Biol Chem (2008) 283:16971-84. doi:10.1074/ jbc.M708459200

100. Jonas C. Rituxan: the new kid on the block. Oncol Nurs Forum (1998) 25:669.

101. Tandan R, Hehir MK II, Waheed W, Howard DB. Rituximab treatment of myasthenia gravis: a systematic review. Muscle Nerve (2017) 56:185-96. doi:10.1002/mus. 25597

102. Schioppo T, Ingegnoli F. Current perspective on rituximab in rheumatic diseases. Drug Des Devel Ther (2017) 11:2891-904. doi:10.2147/DDDT.S139248

103. Joly P, Mouquet H, Roujeau JC, D'Incan M, Gilbert D, Jacquot S, et al. A single cycle of rituximab for the treatment of severe pemphigus. $N$ Engl J Med (2007) 357:545-52. doi:10.1056/NEJMoa067752

104. Cross AH, Stark JL, Lauber J, Ramsbottom MJ, Lyons JA. Rituximab reduces $\mathrm{B}$ cells and $\mathrm{T}$ cells in cerebrospinal fluid of multiple sclerosis patients. J Neuroimmunol (2006) 180:63-70. doi:10.1016/j.jneuroim.2006.06.029

105. Rubbert-Roth A, Tak PP, Zerbini C, Tremblay JL, Carreno L, Armstrong G, et al. Efficacy and safety of various repeat treatment dosing regimens of rituximab in patients with active rheumatoid arthritis: results of a phase III randomized study (MIRROR). Rheumatology (Oxford) (2010) 49:1683-93. doi:10.1093/rheumatology/keq116

106. Degn SE, Thiel S. Humoral pattern recognition and the complement system. Scand J Immunol (2013) 78:181-93. doi:10.1111/sji.12070

107. Wang SY, Weiner G. Complement and cellular cytotoxicity in antibody therapy of cancer. Expert Opin Biol Ther (2008) 8:759-68. doi:10.1517/ 14712598.8.6.759

108. Deans JP, Robbins SM, Polyak MJ, Savage JA. Rapid redistribution of CD20 to a low density detergent-insoluble membrane compartment. J Biol Chem (1998) 273:344-8. doi:10.1074/jbc.273.1.344

109. Cragg MS, Glennie MJ. Antibody specificity controls in vivo effector mechanisms of anti-CD20 reagents. Blood (2004) 103:2738-43. doi:10.1182/ blood-2003-06-2031

110. Lim SH, Beers SA, French RR, Johnson PW, Glennie MJ, Cragg MS. Anti-CD20 monoclonal antibodies: historical and future perspectives. Haematologica (2010) 95:135-43. doi:10.3324/haematol.2008.001628

111. Oldham RJ, Cleary KLS, Cragg MS. CD20 and its antibodies: past, present, and future. For Immunopathol Dis Therap (2014) 5:7-23. doi:10.1615/ ForumImmunDisTher.2015014073

112. Chan HT, Hughes D, French RR, Tutt AL, Walshe CA, Teeling JL, et al. CD20-induced lymphoma cell death is independent of both caspases and its redistribution into triton X-100 insoluble membrane rafts. Cancer Res (2003) 63:5480-9.

113. Teng YK, Wheater G, Hogan VE, Stocks P, Levarht EW, Huizinga TW, et al. Induction of long-term B-cell depletion in refractory rheumatoid arthritis patients preferentially affects autoreactive more than protective humoral immunity. Arthritis Res Ther (2012) 14:R57. doi:10.1186/ar3770

114. Medina F, Segundo C, Campos-Caro A, Gonzalez-Garcia I, Brieva JA. The heterogeneity shown by human plasma cells from tonsil, blood, and bone marrow reveals graded stages of increasing maturity, but local profiles of adhesion molecule expression. Blood (2002) 99:2154-61. doi:10.1182/blood. V99.6.2154

115. Cambridge G, Leandro MJ, Edwards JC, Ehrenstein MR, Salden M, BodmanSmith M, et al. Serologic changes following B lymphocyte depletion therapy for rheumatoid arthritis. Arthritis Rheum (2003) 48:2146-54. doi:10.1002/ art.11181

116. Ahmed AR, Spigelman Z, Cavacini LA, Posner MR. Treatment of pemphigus vulgaris with rituximab and intravenous immune globulin. $N$ Engl J Med (2006) 355:1772-9. doi:10.1056/NEJMoa062930

117. Pfütze M, Eming R, Kneisel A, Kuhlmann U, Hoyer J, Hertl M. Clinical and immunological follow-up of pemphigus patients on adjuvant treatment with immunoadsorption or rituximab. Dermatology (2009) 218:237-45. doi:10.1159/000187431

118. Smolen JS, Landewe R, Bijlsma J, Burmester G, Chatzidionysiou K, Dougados M, et al. EULAR recommendations for the management of rheumatoid arthritis with synthetic and biological disease-modifying antirheumatic drugs: 2016 update. Ann Rheum Dis (2017) 76:960-77. doi:10.1136/annrheumdis2016-210715 
119. Haraoui B, Bokarewa M, Kallmeyer I, Bykerk VP; RESET Investigators. Safety and effectiveness of rituximab in patients with rheumatoid arthritis following an inadequate response to 1 prior tumor necrosis factor inhibitor: the RESET Trial. J Rheumatol (2011) 38:2548-56. doi:10.3899/jrheum.110444

120. De Keyser F, Hoffman I, Durez P, Kaiser MJ, Westhovens R; MIRA Study Group. Longterm followup of rituximab therapy in patients with rheumatoid arthritis: results from the Belgian MabThera in Rheumatoid Arthritis registry. J Rheumatol (2014) 41:1761-5. doi:10.3899/jrheum.131279

121. Gardette A, Ottaviani S, Tubach F, Roy C, Nicaise-Roland P, Palazzo E, et al. High anti-CCP antibody titres predict good response to rituximab in patients with active rheumatoid arthritis. Joint Bone Spine (2014) 81:416-20. doi:10.1016/j.jbspin.2014.06.001

122. Couderc M, Mathieu S, Pereira B, Glace B, Soubrier M. Predictive factors of rituximab response in rheumatoid arthritis: results from a French university hospital. Arthritis Care Res (Hoboken) (2013) 65:648-52. doi:10.1002/acr. 21865

123. Lal P, Su Z, Holweg CT, Silverman GJ, Schwartzman S, Kelman A, et al. Inflammation and autoantibody markers identify rheumatoid arthritis patients with enhanced clinical benefit following rituximab treatment. Arthritis Rheum (2011) 63:3681-91. doi:10.1002/art.30596

124. Chatzidionysiou K, Lie E, Nasonov E, Lukina G, Hetland ML, Tarp U, et al. Highest clinical effectiveness of rituximab in autoantibody-positive patients with rheumatoid arthritis and in those for whom no more than one previous TNF antagonist has failed: pooled data from 10 European registries. Ann Rheum Dis (2011) 70:1575-80. doi:10.1136/ard.2010.148759

125. Sellam J, Riviere E, Courties A, Rouzaire PO, Tolusso B, Vital EM, et al. Serum IL-33, a new marker predicting response to rituximab in rheumatoid arthritis. Arthritis Res Ther (2016) 18:294. doi:10.1186/s13075-016-1190-z

126. Sokolove J, Johnson DS, Lahey LJ, Wagner CA, Cheng D, Thiele GM, et al. Rheumatoid factor as a potentiator of anti-citrullinated protein antibody-mediated inflammation in rheumatoid arthritis. Arthritis Rheumatol (2014) 66:813-21. doi:10.1002/art.38307

127. Cambridge G, Perry HC, Nogueira L, Serre G, Parsons HM, De La Torre I, et al. The effect of B-cell depletion therapy on serological evidence of B-cell and plasmablast activation in patients with rheumatoid arthritis over multiple cycles of rituximab treatment. JAutoimmun (2014) 50:67-76. doi:10.1016/j.jaut.2013.12.002

128. Strober S, Holoshitz J. Mechanisms of immune injury in rheumatoid arthritis: evidence for the involvement of T cells and heat-shock protein. Immunol Rev (1990) 118:233-55. doi:10.1111/j.1600-065X.1990.tb00818.x

129. Roberts CA, Dickinson AK, Taams LS. The interplay between monocytes/ macrophages and CD4(+) T cell subsets in rheumatoid arthritis. Front Immunol (2015) 6:571. doi:10.3389/fimmu.2015.00571

130. Diogo D, Okada Y, Plenge RM. Genome-wide association studies to advance our understanding of critical cell types and pathways in rheumatoid arthritis: recent findings and challenges. Curr Opin Rheumatol (2014) 26:85-92. doi:10.1097/BOR.0000000000000012

131. Esensten JH, Wofsy D, Bluestone JA. Regulatory T cells as therapeutic targets in rheumatoid arthritis. Nat Rev Rheumatol (2009) 5:560-5. doi:10.1038/ nrrheum.2009.183

132. Benucci M, Manfredi M, Puttini PS, Atzeni F. Predictive factors of response to rituximab therapy in rheumatoid arthritis: what do we know today? Autoimmun Rev (2010) 9:801-3. doi:10.1016/j.autrev.2010.07.006

133. Melet J, Mulleman D, Goupille P, Ribourtout B, Watier H, Thibault G. Rituximab-induced $\mathrm{T}$ cell depletion in patients with rheumatoid arthritis: association with clinical response. Arthritis Rheum (2013) 65:2783-90. doi:10.1002/art.38107

134. Wilk E, Witte T, Marquardt N, Horvath T, Kalippke K, Scholz K, et al. Depletion of functionally active CD20+ T cells by rituximab treatment. Arthritis Rheum (2009) 60:3563-71. doi:10.1002/art.24998

135. Barr TA, Brown S, Mastroeni P, Gray D. TLR and B cell receptor signals to B cells differentially program primary and memory Th1 responses to Salmonella enterica. J Immunol (2010) 185:2783-9. doi:10.4049/jimmunol. 1001431

136. Takemura S, Klimiuk PA, Braun A, Goronzy JJ, Weyand CM. T cell activation in rheumatoid synovium is B cell dependent. J Immunol (2001) 167:4710-8. doi:10.4049/jimmunol.167.8.4710

137. Agrawal S, Gupta S. TLR1/2, TLR7, and TLR9 signals directly activate human peripheral blood naive and memory B cell subsets to produce cytokines, chemokines, and hematopoietic growth factors. JClin Immunol (2011) 31:89-98. doi:10.1007/s10875-010-9456-8

138. Rauch PJ, Chudnovskiy A, Robbins CS, Weber GF, Etzrodt M, Hilgendorf I, et al. Innate response activator B cells protect against microbial sepsis. Science (2012) 335:597-601. doi:10.1126/science.1215173

139. Fleischer S, Ries S, Shen P, Lheritier A, Cazals F, Burmester GR, et al. Antiinterleukin- 6 signalling therapy rebalances the disrupted cytokine production of B cells from patients with active rheumatoid arthritis. Eur J Immunol (2017) 48(1):194-203. doi:10.1002/eji.201747191

140. Parekh RB, Roitt IM, Isenberg DA, Dwek RA, Ansell BM, Rademacher TW. Galactosylation of IgG associated oligosaccharides: reduction in patients with adult and juvenile onset rheumatoid arthritis and relation to disease activity. Lancet (1988) 1:966-9. doi:10.1016/S0140-6736(88)91781-3

141. Ercan A, Cui J, Chatterton DE, Deane KD, Hazen MM, Brintnell W, et al. Aberrant IgG galactosylation precedes disease onset, correlates with disease activity, and is prevalent in autoantibodies in rheumatoid arthritis. Arthritis Rheum (2010) 62:2239-48. doi:10.1002/art.27533

142. Kaneko Y, Nimmerjahn F, Ravetch JV. Anti-inflammatory activity of immunoglobulin G resulting from Fc sialylation. Science (2006) 313:670-3. doi:10.1126/science.1129594

143. Collin M, Ehlers M. The carbohydrate switch between pathogenic and immunosuppressive antigen-specific antibodies. Exp Dermatol (2013) 22:511-4. doi:10.1111/exd.12171

144. Reddy V, Martinez L, Isenberg DA, Leandro MJ, Cambridge G. Pragmatic treatment of patients with systemic lupus erythematosus with rituximab: long-term effects on serum immunoglobulins. Arthritis Care Res (Hoboken) (2017) 69:857-66. doi:10.1002/acr.22993

145. Rovin BH, Furie R, Latinis K, Looney RJ, Fervenza FC, Sanchez-Guerrero J, et al. Efficacy and safety of rituximab in patients with active proliferative lupus nephritis: the lupus nephritis assessment with rituximab study. Arthritis Rheum (2012) 64:1215-26. doi:10.1002/art.34359

146. Leandro MJ, Cambridge G, Edwards JC, Ehrenstein MR, Isenberg DA. B-cell depletion in the treatment of patients with systemic lupus erythematosus: a longitudinal analysis of 24 patients. Rheumatology (Oxford) (2005) 44:1542-5. doi:10.1093/rheumatology/kei080

147. Albert D, Dunham J, Khan S, Stansberry J, Kolasinski S, Tsai D, et al. Variability in the biological response to anti-CD20 B cell depletion in systemic lupus erythaematosus. Ann Rheum Dis (2008) 67:1724-31. doi:10.1136/ ard.2007.083162

148. Lu TY, Ng KP, Cambridge G, Leandro MJ, Edwards JC, Ehrenstein M, et al. A retrospective seven-year analysis of the use of $\mathrm{B}$ cell depletion therapy in systemic lupus erythematosus at University College London Hospital: the first fifty patients. Arthritis Rheum (2009) 61:482-7. doi:10.1002/art.24341

149. Hauser SL, Waubant E, Arnold DL, Vollmer T, Antel J, Fox RJ, et al. B-cell depletion with rituximab in relapsing-remitting multiple sclerosis. $N$ Engl J Med (2008) 358:676-88. doi:10.1056/NEJMoa0706383

150. Dunn N, Juto A, Ryner M, Manouchehrinia A, Piccoli L, Fink K, et al. Rituximab in multiple sclerosis: frequency and clinical relevance of anti-drug antibodies. Mult Scler (2017):1352458517720044. doi:10.1177/1352458517720044

151. Hawker K, O'Connor P, Freedman MS, Calabresi PA, Antel J, Simon J, et al. Rituximab in patients with primary progressive multiple sclerosis: results of a randomized double-blind placebo-controlled multicenter trial. Ann Neurol (2009) 66:460-71. doi:10.1002/ana.21867

152. Fillatreau S, Gray D, Anderton SM. Not always the bad guys: B cells as regulators of autoimmune pathology. Nat Rev Immunol (2008) 8:391-7. doi:10.1038/nri2315

153. Matsumoto M, Baba A, Yokota T, Nishikawa H, Ohkawa Y, Kayama H, et al. Interleukin-10-producing plasmablasts exert regulatory function in autoimmune inflammation. Immunity (2014) 41:1040-51. doi:10.1016/j. immuni.2014.10.016

154. Du FH, Mills EA, Mao-Draayer Y. Next-generation anti-CD20 monoclonal antibodies in autoimmune disease treatment. Auto Immun Highlights (2017) 8:12. doi:10.1007/s13317-017-0100-y

155. Emery P, Rigby W, Tak PP, Dorner T, Olech E, Martin C, et al. Safety with ocrelizumab in rheumatoid arthritis: results from the ocrelizumab phase III program. PLoS One (2014) 9:e87379. doi:10.1371/journal.pone. 0087379

156. Hammer O. CD19 as an attractive target for antibody-based therapy. MAbs (2012) 4:571-7. doi:10.4161/mabs.21338 
157. Jabbour E, Ravandi F, Kebriaei P, Huang X, Short NJ, Thomas D, et al. Salvage chemoimmunotherapy with inotuzumab ozogamicin combined with mini-hyper-CVD for patients with relapsed or refractory philadelphia chromosome-negative acute lymphoblastic leukemia: a phase 2 clinical trial. JAMA Oncol (2018) 4:230-4. doi:10.1001/jamaoncol.2017.2380

158. Tedder TF. CD19: a promising B cell target for rheumatoid arthritis. Nat Rev Rheumatol (2009) 5:572-7. doi:10.1038/nrrheum.2009.184

159. Gopaluni S, Smith RM, Lewin M, McAlear CA, Mynard K, Jones RB, et al. Rituximab versus azathioprine as therapy for maintenance of remission for anti-neutrophil cytoplasm antibody-associated vasculitis (RITAZAREM): study protocol for a randomized controlled trial. Trials (2017) 18:112. doi:10.1186/s13063-017-1857-z

160. Bossen C, Schneider P. BAFF, APRIL and their receptors: structure, function and signaling. Semin Immunol (2006) 18:263-75. doi:10.1016/j.smim. 2006.04.006

161. Gross JA, Johnston J, Mudri S, Enselman R, Dillon SR, Madden K, et al. TACI and BCMA are receptors for a TNF homologue implicated in B-cell autoimmune disease. Nature (2000) 404:995-9. doi:10.1038/35010115

162. Condon MB, Ashby D, Pepper RJ, Cook HT, Levy JB, Griffith M, et al. Prospective observational single-centre cohort study to evaluate the effectiveness of treating lupus nephritis with rituximab and mycophenolate mofetil but no oral steroids. Ann Rheum Dis (2013) 72:1280-6. doi:10.1136/ annrheumdis-2012-202844

163. Ramos-Casals M, Garcia-Hernandez FJ, de Ramon E, Callejas JL, MartinezBerriotxoa A, Pallares L, et al. Off-label use of rituximab in 196 patients with severe, refractory systemic autoimmune diseases. Clin Exp Rheumatol (2010) 28:468-76.

164. Blair HA, Duggan ST. Belimumab: a review in systemic lupus erythematosus. Drugs (2018) 78:355-66. doi:10.1007/s40265-018-0872-Z

165. Jacobi AM, Huang W, Wang T, Freimuth W, Sanz I, Furie R, et al. Effect of long-term belimumab treatment on B cells in systemic lupus erythematosus: extension of a phase II, double-blind, placebo-controlled, dose-ranging study. Arthritis Rheum (2010) 62:201-10. doi:10.1002/art.27189

166. Ginzler EM, Wallace DJ, Merrill JT, Furie RA, Stohl W, Chatham WW, et al. Disease control and safety of belimumab plus standard therapy over 7 years in patients with systemic lupus erythematosus. J Rheumatol (2014) 41:300-9. doi:10.3899/jrheum.121368

167. Stohl W, Hiepe F, Latinis KM, Thomas M, Scheinberg MA, Clarke A, et al. Belimumab reduces autoantibodies, normalizes low complement levels, and reduces select B cell populations in patients with systemic lupus erythematosus. Arthritis Rheum (2012) 64:2328-37. doi:10.1002/art.34400

168. Smolen JS, Weinblatt ME, van der Heijde D, Rigby WF, van Vollenhoven R, Bingham CO III, et al. Efficacy and safety of tabalumab, an anti-B-cellactivating factor monoclonal antibody, in patients with rheumatoid arthritis who had an inadequate response to methotrexate therapy: results from a phase III multicentre, randomised, double-blind study. Ann Rheum Dis (2015) 74:1567-70. doi:10.1136/annrheumdis-2014-207090

169. Greenwald M, Szczepanski L, Kennedy A, Veenhuizen M, Komocsar WJ, Polasek E, et al. A 52-week, open-label study evaluating the safety and efficacy of tabalumab, an anti-B-cell-activating factor monoclonal antibody, for rheumatoid arthritis. Arthritis Res Ther (2014) 16:415. doi:10.1186/ s13075-014-0415-2

170. Genovese MC, Kinnman N, de La Bourdonnaye G, Pena Rossi C, Tak PP. Atacicept in patients with rheumatoid arthritis and an inadequate response to tumor necrosis factor antagonist therapy: results of a phase II, randomized, placebo-controlled, dose-finding trial. Arthritis Rheum (2011) 63:1793-803. doi:10.1002/art.30373

171. van Vollenhoven RF, Kinnman N, Vincent E, Wax S, Bathon J. Atacicept in patients with rheumatoid arthritis and an inadequate response to methotrexate: results of a phase II, randomized, placebo-controlled trial. Arthritis Rheum (2011) 63:1782-92. doi:10.1002/art.30372

172. Navarra SV, Guzman RM, Gallacher AE, Hall S, Levy RA, Jimenez RE, et al. Efficacy and safety of belimumab in patients with active systemic lupus erythematosus: a randomised, placebo-controlled, phase 3 trial. Lancet (2011) 377:721-31. doi:10.1016/S0140-6736(10)61354-2

173. Furie R, Petri M, Zamani O, Cervera R, Wallace DJ, Tegzova D, et al. A phase III, randomized, placebo-controlled study of belimumab, a monoclonal antibody that inhibits B lymphocyte stimulator, in patients with systemic lupus erythematosus. Arthritis Rheum (2011) 63:3918-30. doi:10.1002/art.30613
174. Merrill JT, van Vollenhoven RF, Buyon JP, Furie RA, Stohl W, Morgan-Cox M, et al. Efficacy and safety of subcutaneous tabalumab, a monoclonal antibody to B-cell activating factor, in patients with systemic lupus erythematosus: results from ILLUMINATE-2, a 52-week, phase III, multicentre, randomised, double-blind, placebo-controlled study. Ann Rheum Dis (2016) 75:332-40. doi:10.1136/annrheumdis-2015-207654

175. Furie RA, Leon G, Thomas M, Petri MA, Chu AD, Hislop C, et al. A phase 2, randomised, placebo-controlled clinical trial of blisibimod, an inhibitor of $B$ cell activating factor, in patients with moderate-to-severe systemic lupus erythematosus, the PEARL-SC study. Ann Rheum Dis (2015) 74:1667-75. doi:10.1136/annrheumdis-2013-205144

176. Dall'Era M, Chakravarty E, Wallace D, Genovese M, Weisman M, Kavanaugh A, et al. Reduced B lymphocyte and immunoglobulin levels after atacicept treatment in patients with systemic lupus erythematosus: results of a multicenter, phase Ib, double-blind, placebo-controlled, dose-escalating trial. Arthritis Rheum (2007) 56:4142-50. doi:10.1002/art.23047

177. Lenert P, Icardi M, Dahmoush L. ANA (+) ANCA (+) systemic vasculitis associated with the use of minocycline: case-based review. Clin Rheumatol (2013) 32:1099-106. doi:10.1007/s10067-013-2245-Z

178. Ginzler EM, Wax S, Rajeswaran A, Copt S, Hillson J, Ramos E, et al. Atacicept in combination with MMF and corticosteroids in lupus nephritis: results of a prematurely terminated trial. Arthritis Res Ther (2012) 14:R33. doi:10.1186/ar3738

179. Mariette X, Seror R, Quartuccio L, Baron G, Salvin S, Fabris M, et al. Efficacy and safety of belimumab in primary Sjogren's syndrome: results of the BELISS open-label phase II study. Ann Rheum Dis (2015) 74:526-31. doi:10.1136/ annrheumdis-2013-203991

180. Kappos L, Hartung HP, Freedman MS, Boyko A, Radu EW, Mikol DD, et al. Atacicept in multiple sclerosis (ATAMS): a randomised, placebo-controlled, double-blind, phase 2 trial. Lancet Neurol (2014) 13:353-63. doi:10.1016/ S1474-4422(14)70028-6

181. Stohl W, Merrill JT, McKay JD, Lisse JR, Zhong ZJ, Freimuth WW, et al. Efficacy and safety of belimumab in patients with rheumatoid arthritis: a phase II, randomized, double-blind, placebo-controlled, dose-ranging study. J Rheumatol (2013) 40:579-89. doi:10.3899/jrheum.120886

182. Manz RA, Thiel A, Radbruch A. Lifetime of plasma cells in the bone marrow. Nature (1997) 388:133-4. doi:10.1038/40540

183. Slifka MK, Antia R, Whitmire JK, Ahmed R. Humoral immunity due to long-lived plasma cells. Immunity (1998) 8:363-72. doi:10.1016/S10747613(00)80541-5

184. Bontscho J, Schreiber A, Manz RA, Schneider W, Luft FC, Kettritz R. Myeloperoxidase-specific plasma cell depletion by bortezomib protects from anti-neutrophil cytoplasmic autoantibodies-induced glomerulonephritis. J Am Soc Nephrol (2011) 22:336-48. doi:10.1681/ASN.2010010034

185. Gomez AM, Vrolix K, Martinez-Martinez P, Molenaar PC, Phernambucq M, van der Esch E, et al. Proteasome inhibition with bortezomib depletes plasma cells and autoantibodies in experimental autoimmune myasthenia gravis. J Immunol (2011) 186:2503-13. doi:10.4049/jimmunol.1002539

186. Taddeo A, Khodadadi L, Voigt C, Mumtaz IM, Cheng Q, Moser K, et al. Long-lived plasma cells are early and constantly generated in New Zealand Black/New Zealand White F1 mice and their therapeutic depletion requires a combined targeting of autoreactive plasma cells and their precursors. Arthritis Res Ther (2015) 17:39. doi:10.1186/s13075-015-0551-3

187. Rosenberg AS, Pariser AR, Diamond B, Yao L, Turka LA, Lacana E, et al. A role for plasma cell targeting agents in immune tolerance induction in autoimmune disease and antibody responses to therapeutic proteins. Clin Immunol (2016) 165:55-9. doi:10.1016/j.clim.2016.02.009

188. Mehta B, Mahadeo K, Zaw R, Tang S, Kapoor N, Abdel-Azim H. Bortezomib for effective treatment of a child with refractory autoimmune hemolytic anemia post allogeneic hematopoietic stem cell transplant. Pediatr Blood Cancer (2014) 61:2324-5. doi:10.1002/pbc.25172

189. Jakez-Ocampo J, Atisha-Fregoso Y, Llorente L. Refractory primary Sjogren syndrome successfully treated with bortezomib. J Clin Rheumatol (2015) 21:31-2. doi:10.1097/RHU.0000000000000210

190. Verbrugge SE, Scheper RJ, Lems WF, de Gruijl TD, Jansen G. Proteasome inhibitors as experimental therapeutics of autoimmune diseases. Arthritis Res Ther (2015) 17:17. doi:10.1186/s13075-015-0529-1

191. Khandelwal P, Davies SM, Grimley MS, Jordan MB, Curtis BR, Jodele S, et al. Bortezomib for refractory autoimmunity in pediatrics. Biol Blood Marrow Transplant (2014) 20:1654-9. doi:10.1016/j.bbmt.2014.06.032 
192. Yates S, Matevosyan K, Rutherford C, Shen YM, Sarode R. Bortezomib for chronic relapsing thrombotic thrombocytopenic purpura: a case report. Transfusion (2014) 54:2064-7. doi:10.1111/trf.12614

193. van Balen T, Schreuder MF, de Jong H, van de Kar NC. Refractory thrombotic thrombocytopenic purpura in a 16-year-old girl: successful treatment with bortezomib. Eur J Haematol (2014) 92:80-2. doi:10.1111/ejh.12206

194. Gomez AM, Willcox N, Molenaar PC, Buurman W, Martinez-Martinez P, De Baets $\mathrm{MH}$, et al. Targeting plasma cells with proteasome inhibitors: possible roles in treating myasthenia gravis? Ann N Y Acad Sci (2012) 1274:48-59. doi:10.1111/j.1749-6632.2012.06824.x

195. Danchaivijitr P, Yared J, Rapoport AP. Successful treatment of IgG and complement-mediated autoimmune hemolytic anemia with bortezomib and low-dose cyclophosphamide. Am J Hematol (2011) 86:331-2. doi:10.1002/ ajh. 21950

196. Hiepe F, Radbruch A. Plasma cells as an innovative target in autoimmune disease with renal manifestations. Nat Rev Nephrol (2016) 12:232-40. doi:10.1038/nrneph.2016.20

197. Hiepe F, Dorner T, Hauser AE, Hoyer BF, Mei H, Radbruch A. Long-lived autoreactive plasma cells drive persistent autoimmune inflammation. Nat Rev Rheumatol (2011) 7:170-8. doi:10.1038/nrrheum.2011.1

198. Mauri C, Menon M. The expanding family of regulatory B cells. Int Immunol (2015) 27:479-86. doi:10.1093/intimm/dxv038

199. van der Vlugt LE, Labuda LA, Ozir-Fazalalikhan A, Lievers E, Gloudemans AK, Liu KY, et al. Schistosomes induce regulatory features in human and mouse CD1d(hi) B cells: inhibition of allergic inflammation by IL-10 and regulatory T cells. PLoS One (2012) 7:e30883. doi:10.1371/journal.pone.0030883

200. Korniotis S, Gras C, Letscher H, Montandon R, Megret J, Siegert S, et al. Treatment of ongoing autoimmune encephalomyelitis with activated B-cell progenitors maturing into regulatory B cells. Nat Commun (2016) 7:12134. doi:10.1038/ncomms12134

201. Mauri C, Bosma A. Immune regulatory function of B cells. Annu Rev Immunol (2012) 30:221-41. doi:10.1146/annurev-immunol-020711-074934

202. Egwuagu CE, Yu CR. Interleukin 35-producing B cells (i35-Breg): a new mediator of regulatory B-cell functions in CNS autoimmune diseases. Crit Rev Immunol (2015) 35:49-57. doi:10.1615/CritRevImmunol.2015012558

203. Rosser EC, Mauri C. Regulatory B cells: origin, phenotype, and function. Immunity (2015) 42:607-12. doi:10.1016/j.immuni.2015.04.005

204. Blair PA, Norena LY, Flores-Borja F, Rawlings DJ, Isenberg DA, Ehrenstein MR, et al. CD19(+)CD24(hi)CD38(hi) B cells exhibit regulatory capacity in healthy individuals but are functionally impaired in systemic lupus erythematosus patients. Immunity (2010) 32:129-40. doi:10.1016/j.immuni.2009. 11.009

205. de Masson A, Bouaziz JD, Le Buanec H, Robin M, O’Meara A, Parquet N, et al. CD24(hi)CD27(+) and plasmablast-like regulatory B cells in human chronic graft-versus-host disease. Blood (2015) 125:1830-9. doi:10.1182/ blood-2014-09-599159

206. Banko Z, Pozsgay J, Szili D, Toth M, Gati T, Nagy G, et al. Induction and differentiation of IL-10-producing regulatory B cells from healthy blood donors and rheumatoid arthritis patients. J Immunol (2017) 198:1512-20. doi:10.4049/jimmunol.1600218

207. Iwata Y, Matsushita T, Horikawa M, Dilillo DJ, Yanaba K, Venturi GM, et al. Characterization of a rare IL-10-competent B-cell subset in humans that parallels mouse regulatory B10 cells. Blood (2011) 117:530-41. doi:10.1182/ blood-2010-07-294249

208. Heine G, Drozdenko G, Grun JR, Chang HD, Radbruch A, Worm M. Autocrine IL-10 promotes human B-cell differentiation into IgM- or IgGsecreting plasmablasts. Eur J Immunol (2014) 44:1615-21. doi:10.1002/eji. 201343822

209. Zhu HQ, Xu RC, Chen YY, Yuan HJ, Cao H, Zhao XQ, et al. Impaired function of CD19(+) CD24(hi) CD38(hi) regulatory B cells in patients with pemphigus. Br J Dermatol (2015) 172:101-10. doi:10.1111/bjd.13192

210. Daien CI, Gailhac S, Mura T, Audo R, Combe B, Hahne M, et al. Regulatory B10 cells are decreased in patients with rheumatoid arthritis and are inversely correlated with disease activity. Arthritis Rheumatol (2014) 66:2037-46. doi:10.1002/art.38666

211. Salomon S, Guignant C, Morel P, Flahaut G, Brault C, Gourguechon C, et al. Th17 and CD24hiCD27+ regulatory B lymphocytes are biomarkers of response to biologics in rheumatoid arthritis. Arthritis Res Ther (2017) 19:33. doi:10.1186/s13075-017-1244-x
212. Flores-Borja F, Bosma A, Ng D, Reddy V, Ehrenstein MR, Isenberg DA, et al. CD19+CD24hiCD38hi B cells maintain regulatory $\mathrm{T}$ cells while limiting TH1 and TH17 differentiation. Sci Transl Med (2013) 5:173ra23. doi:10.1126/ scitranslmed.3005407

213. Matsushita T, Hamaguchi Y, Hasegawa M, Takehara K, Fujimoto M. Decreased levels of regulatory B cells in patients with systemic sclerosis: association with autoantibody production and disease activity. Rheumatology (Oxford) (2016) 55:263-7. doi:10.1093/rheumatology/kev331

214. Aravena O, Ferrier A, Menon M, Mauri C, Aguillon JC, Soto L, et al. TIM-1 defines a human regulatory B cell population that is altered in frequency and function in systemic sclerosis patients. Arthritis Res Ther (2017) 19:8. doi:10.1186/s13075-016-1213-9

215. Duddy M, Niino M, Adatia F, Hebert S, Freedman M, Atkins H, et al. Distinct effector cytokine profiles of memory and naive human B cell subsets and implication in multiple sclerosis. J Immunol (2007) 178:6092-9. doi:10.4049/ jimmunol.178.10.6092

216. Bar-Or A, Fawaz L, Fan B, Darlington PJ, Rieger A, Ghorayeb C, et al. Abnormal B-cell cytokine responses a trigger of T-cell-mediated disease in MS? Ann Neurol (2010) 67:452-61. doi:10.1002/ana.21939

217. Knippenberg S, Peelen E, Smolders J, Thewissen M, Menheere P, Cohen Tervaert JW, et al. Reduction in IL-10 producing B cells (Breg) in multiple sclerosis is accompanied by a reduced naive/memory Breg ratio during a relapse but not in remission. J Neuroimmunol (2011) 239:80-6. doi:10.1016/j. jneuroim.2011.08.019

218. Miyagaki T, Fujimoto M, Sato S. Regulatory B cells in human inflammatory and autoimmune diseases: from mouse models to clinical research. Int Immunol (2015) 27:495-504. doi:10.1093/intimm/dxv026

219. Sun F, Ladha SS, Yang L, Liu Q, Shi SX, Su N, et al. Interleukin-10 producing-B cells and their association with responsiveness to rituximab in myasthenia gravis. Muscle Nerve (2014) 49:487-94. doi:10.1002/mus.23951

220. Wang Q, Racine JJ, Ratiu JJ, Wang S, Ettinger R, Wasserfall C, et al. Transient BAFF blockade inhibits type 1 diabetes development in nonobese diabetic mice by enriching immunoregulatory B lymphocytes sensitive to deletion by anti-CD20 cotherapy. J Immunol (2017) 199:3757-70. doi:10.4049/ jimmunol.1700822

221. Colliou N, Picard D, Caillot F, Calbo S, Le Corre S, Lim A, et al. Long-term remissions of severe pemphigus after rituximab therapy are associated with prolonged failure of desmoglein B cell response. Sci Transl Med (2013) 5:175ra30. doi:10.1126/scitranslmed.3005166

222. Menon M, Blair PA, Isenberg DA, Mauri C. A regulatory feedback between plasmacytoid dendritic cells and regulatory B cells is aberrant in systemic lupus erythematosus. Immunity (2016) 44:683-97. doi:10.1016/j. immuni.2016.02.012

223. Merrill JT, Burgos-Vargas R, Westhovens R, Chalmers A, D'Cruz D, Wallace DJ, et al. The efficacy and safety of abatacept in patients with non-life-threatening manifestations of systemic lupus erythematosus: results of a twelve-month, multicenter, exploratory, phase IIb, randomized, double-blind, placebo-controlled trial. Arthritis Rheum (2010) 62:3077-87. doi:10.1002/art.27601

224. Giacomini E, Rizzo F, Etna MP, Cruciani M, Mechelli R, Buscarinu MC, et al. Thymosin-alpha1 expands deficient IL-10-producing regulatory B cell subsets in relapsing-remitting multiple sclerosis patients. Mult Scler (2017) 24(2):127-39. doi:10.1177/1352458517695892

225. Rosser EC, Oleinika K, Tonon S, Doyle R, Bosma A, Carter NA, et al Regulatory B cells are induced by gut microbiota-driven interleukin-1beta and interleukin-6 production. Nat Med (2014) 20:1334-9. doi:10.1038/ nm. 3680

226. Wang RX, Yu CR, Dambuza IM, Mahdi RM, Dolinska MB, Sergeev YV, et al. Interleukin-35 induces regulatory B cells that suppress autoimmune disease. Nat Med (2014) 20:633-41. doi:10.1038/nm.3554

227. Mauri C, Menon M. Human regulatory B cells in health and disease: therapeutic potential. J Clin Invest (2017) 127:772-9. doi:10.1172/JCI85113

228. Yanaba K, Bouaziz JD, Haas KM, Poe JC, Fujimoto M, Tedder TF. A regulatory B cell subset with a unique CD1dhiCD5+ phenotype controls T celldependentinflammatory responses. Immunity (2008) 28:639-50. doi:10.1016/ j.immuni.2008.03.017

229. O'Garra A, Chang R, Go N, Hastings R, Haughton G, Howard M. Ly-1 B (B-1) cells are the main source of B cell-derived interleukin 10. Eur J Immunol (1992) 22:711-7. doi:10.1002/eji.1830220314 
230. Evans JG, Chavez-Rueda KA, Eddaoudi A, Meyer-Bahlburg A, Rawlings DJ, Ehrenstein MR, et al. Novel suppressive function of transitional 2 B cells in experimental arthritis. JImmunol (2007) 178:7868-78. doi:10.4049/ jimmunol.178.12.7868

231. Gray M, Miles K, Salter D, Gray D, Savill J. Apoptotic cells protect mice from autoimmune inflammation by the induction of regulatory B cells. Proc Natl Acad Sci U S A (2007) 104:14080-5. doi:10.1073/pnas.0700326104

232. Maseda D, Smith SH, DiLillo DJ, Bryant JM, Candando KM, Weaver CT, et al. Regulatory B10 cells differentiate into antibody-secreting cells after transient IL-10 production in vivo. J Immunol (2012) 188:1036-48. doi:10.4049/ jimmunol.1102500
Conflict of Interest Statement: The authors declare that the research was conducted in the absence of any commercial or financial relationships that could be construed as a potential conflict of interest.

Copyright $\odot 2018$ Hofmann, Clauder and Manz. This is an open-access article distributed under the terms of the Creative Commons Attribution License (CC BY).

The use, distribution or reproduction in other forums is permitted, provided the original author(s) and the copyright owner are credited and that the original publication in this journal is cited, in accordance with accepted academic practice. No use, distribution or reproduction is permitted which does not comply with these terms. 